Utrecht School of Economics

Tjalling C. Koopmans Research Institute

Discussion Paper Series 06-03

\title{
Cross-Border Takeovers, Corruption, and Related Aspects of Governance
}

\author{
Utz Weitzela \\ Sjors Berns ${ }^{b}$ \\ ${ }^{a}$ Utrecht School of Economics \\ Utrecht University

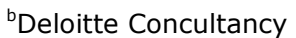 \\ Utrecht
}

May 2006

\begin{abstract}
We use a panel of 4979 cross-border and domestic takeovers to test the relation between host country corruption and premiums paid for local targets. Host country corruption is negatively associated with target premiums, after correcting for other governance related factors such as political stability, legal systems, and financial disclosure standards. We estimate that deterioration in the corruption index by one point (on a ten point scale) is, on average, associated with a reduction of $21 \%$ of local targets' premiums. Our results do not support the notion that local corruption constitutes a significant market barrier to foreign investors. It rather represents a discount on local takeover synergies, which affects foreign and domestic acquirers alike. However, we find that the major effects of corruption can alternatively be explained by government effectiveness, pointing towards an endogenous relationship between bribery and bureaucracy.
\end{abstract}

Keywords: corruption, mergers and acquisitions, multinational enterprise, governance, foreign direct investment, institutions

\section{Acknowledgements}

We thank Harry Garretsen, Gerrit Faber, Gerhard Kling, Peter Rodriguez, and four anonymous referees for insightful comments. We also thank Nico den Hartog for his help with the collection of the data.

The usual disclaimer apply. 


\section{Introduction}

Despite a number of studies on corruption and foreign direct investment (FDI), only a few focus on the association between corruption and cross-border takeovers. ${ }^{1}$ This is somewhat surprising since mergers and acquisitions (M\&A) have been increasing their share of FDI in recent years and have become a primary mode of internationalization (UNCTAD, 2000). At about the same time, corruption was broadly recognized as a global phenomenon with an astounding volume of annual bribery, estimated at about 1 trillion US\$; excluding nepotism, theft of public assets, and corrupt leakages from public budgets (Kaufmann, 2005).

Corruption is widely seen as one of the foremost problems in developing countries (e.g. Bardhan, 1997), although "available data indicate clearly that ethics and corruption represent a challenge not only for many emerging economies, but also for many countries of the rich world." (Kaufmann, 2004, p.83). Next to corruption, bureaucracy is also considered a serious constraint on governance in developing and developed nations alike (Kaufmann, 2005). In this study we therefore include several other aspects of governance, which are related to corruption, such as government effectiveness, political stability, and legal origin, and analyze their relationship with prices paid for the takeover of local corporate assets.

Prior research on corruption largely focused on aggregated macroeconomic data at the country level. In a seminal paper, Mauro (1995) reported econometric evidence for a negative correlation between corruption and the ratio of investment to GDP, as well as economic growth, in a cross-section of countries. ${ }^{2}$ A number of subsequent empirical studies strengthened and qualified this finding, not only for a country's total investment ratio (Keefer and Knack, 1995; Brunetti and Weder, 1998), but also for foreign direct investment (Hines, 1995; Henisz, 2000; Wei, 2000; Wei, 2000a; Habib and Zurawicki, 2001, 2002; Robertson and Watson, 2004; Zhao et al., 2003).

However, recent literature in this and related fields increasingly stresses the importance of firm- or transaction-level analyses (Rossi and Volpin, 2004, Habib and Zurawicki, 2002). With the exception of Henisz (2000) and Smarzynska and Wei (2000) only few empirical studies analyze the effect of corruption on cross-border M\&A and simultaneously consider

\footnotetext{
${ }^{1}$ We use the terms merger, acquisition, takeover, transaction, and deal synonymously. M\&A is used as the standard abbreviation for all of these terms.

2 Mauro (1995) finds this relationship for a subjective index of corruption, as well as for bureaucratic efficiency, which he computed as the average of three indices from Business International (now The Economist Intelligence Unit): degree of corruption, amount of red tape, and efficiency and integrity of the judicial system.
} 
country-, firm-, and transaction-level characteristics as well as institutional attributes. While both these studies analyze majority ownership as a possible mode of entry, our paper studies prices paid for local corporate assets, when foreign investors take over a domestic target. Here, our main focus lies on the role of corruption in the target's country, which we define as 'abuse of public power for private gain'.

To the best of our knowledge, this is the first study that empirically analyzes the relationship between local corruption and takeover premiums. As such, it may contribute new insights on corruption at the firm- and transaction-level, and also add to the analysis of international M\&As, where research has not kept pace with the growing popularity of this type of diversification strategy (Shimizu et al., 2004).

The paper is structured as follows. In the next section we will develop our hypotheses from prior research. In the subsequent sections, the variables, data, and empirical results will be presented. The paper concludes with a discussion of the most important implications.

\section{Development of hypotheses}

The literature on FDI (surveyed by e.g. Froot, 1993), cross-border takeovers (surveyed by e.g. Shimizu et al., 2004), and on corruption (surveyed by e.g. Bardhan, 1997) is simply too vast to be comprehensively covered here. In the following we therefore only cite those studies, which directly advance the development of our hypotheses.

\subsection{Corruption as a market barrier to entry}

Many studies on FDI and corruption assume that foreign firms are outsiders to host country corruption and sometimes seek a local partner in order to gain access to the host market (see e.g. Smarzynska and Wei, 2000; Henisz, 2000; Uhlenbruck et al., 2006). This is supported by Lambsdorff (2002), who argues that corrupt environments often lead to the employment of brokers, middlemen and local partners. Here, the crucial assumption is that transaction costs of corruption are high (Husted, 1994). In fact, a distinctive feature of corruption (e.g. in comparison to lobbying) is its 'lock-in' effect. Due to the ever-present threat of mutual denunciation partners are tied to each other even after the exchange. Corruption thus raises the barriers to entry and exit of corrupt markets, restrains exchange to insiders, and augments the importance of local partners (Lambsdorff, 2002; Rose-Ackerman, 1999; Habib and Zurawicki, 2002, p.293). As corruption raises the barriers to entry, the relative importance and bargaining power of the target may also increase.

How does this translate into variations in target premiums? As Equation 1 shows, the premium paid to target shareholders is the final bid price of the acquirer over the (stand alone) market value of the target before the merger. If the premium is greater than 1 , the final bid 
price does not only include the pre-merger market value of the target, but also the target's share of the incremental net present value of joint merger synergies. Merger synergies represent added value from the unique business combination, e.g. economies of scale or scope, over and above the sum of the two stand alone values (of the acquirer and the target). target premium $=\frac{\text { final bid price }}{\text { stand alone value }}=1+$ target's percentage $\cdot\left(\frac{\text { joint synergies }}{\text { stand alone value }}\right)$

How the anticipated synergies are split between the two parties is inter alia determined by the bargaining power of the target in merger negotiations. If corruption is associated with higher entry barriers, this may c.p. improve the bargaining position of the target, since its status as an insider becomes more important. Consequently, the target may be able to claim a higher share of joint synergies. Transferred into Equation 1, the target's percentage of joint synergies - and c.p. the premium - would be higher than without local corruption. This also holds when foreign acquirers use outside options, e.g. greenfield investments, to mitigate the target's raised claim on synergies. Bargaining theory suggests that when market barriers to entry lower the outside option of the acquirer (e.g. expected profits of an alternative greenfield entry), the remaining synergies that both parties can still bargain over are increased, which leads to c.p. higher target premiums (Mutthoo, 1999) ${ }^{3}$ If mergers, compared to other forms of FDI, are more sought after in markets with high barriers to entry, increased bidding competition can constitute another reason why targets' percentage of joint synergies in Equation 1 may be higher in more corrupt countries. Following Chang and Rosenzweig (2001), it is reasonable to expect thatforeign firms try to use acquisitions rather than greenfield entries to get around market barriers, effectively increasing bidding competition and thus target premiums. However, in contrast to the bargaining power rationale, this reasoning has the caveat that the intensity of bidding competition is also determined by a number of other factors, ranging from capital controls and foreign ownership restrictions, in particular, to host countries' attractivity for FDI in general.

\footnotetext{
${ }^{3}$ As a simple illustrative example, consider merger synergies of $\$ 100$ and an expected greenfield profit of $\$ 90$, when there are no market barriers. In this case the the 'net' synergies that remain to be bargained over after considering the parties' outside options (referred to as 'gains of trade' in the bargaining literature) would be $\$ 10$ (\$100 total synergies minus $\$ 90$ greenfield profit as outside option). In line with the Nash bargaining solution we assume that the gains of trade are split evenly between both parties generating a target premium of $\$ 5$. For a corruption szenario we lower greenfield profits to $\$ 40$ due to extra costs for outsiders (market barrier to entry). Now, the gains of trade for same takeover are $\$ 100-\$ 40=\$ 60$, allowing c.p. a target premium of $\$ 30$ (evenly split).
} 
We therefore attempt to control for a number of these determinants (including the number of bidders), which will be explained in conjunction with the econometric specification.

However, it is important to note, that the following hypothesis does not primarily depend on bidding competition. If corruption is associated with or independently represents a higher market barrier to entry for foreign firms, both, through either the bargaining power rationale or bidding competition rationale, we would expect the following:

Hypothesis 1a: Target premiums and corruption of the host country are positively related in cross-border takeovers.

A significant body of literature, particular with respect to cultural determinants, suggests that not only the absolute level of country characteristics, but also the difference between the home and the host country, play an important role in International Business (IB) (see Harzing (2003) and Shimizu et al. (2004) for surveys on cultural distance studies focusing on entry mode decisions and cross-border M\&As, respectively). From the theoretical arguments above, we can infer that the absolute difference between the corruption levels of the home and host country is related to higher transaction costs for outsiders, facilitating higher market barriers and higher premiums that may be paid to overcome them According to this notion, an acquirer from Sweden (low corruption index of 0.71 ) with presumably limited experience in corruption, would be willing to pay a higher premium to gain access to a target's insider knowledge of local corruption in Indonesia (7.95), than an acquirer from Thailand (6.81). Note, that the corruption distance is an absolute measure, which does not differentiate between acquirers from less corrupt or more corrupt countries. We thus assume that attempting to bribe when bribery is not a custom affects transaction costs in a similar way as not bribing when grafts are expected.

Hypothesis 2a: Target premiums and the absolute difference of corruption between the home and the host country are positively related in cross-border takeovers.

For domestic mergers, the above logic implies that the local corruption level is unrelated to premiums: the corruption distance between the acquirer and target is zero, with no effects on host country market barriers or on relative advantages of an insider, such that the bargaining power of both parties is expected to be independent of corruption. We will use this prediction as a robustness check for Hypothesis $2 \mathrm{a}$.

\subsection{Corruption as a discount on merger synergies}

The underlying assumption of hypotheses $1 \mathrm{a}$ and $2 \mathrm{a}$ is that corruption may influence transaction costs in the form of market barriers, which have an effect on the distribution of takeover synergies between acquirers and targets, but not on the level of joint synergies. 
However, this one-dimensional impact is not warranted as the secretive nature of corruption adds significant uncertainty to the returns of local investments (Pellegrini and Gerlagh, 2004; Drabek and Payne, 2002; Rodriguez et al., 2005). Host country corruption forces acquirers to include several potentially unknown factors in their estimation of joint synergies, including the risk to lose public procurement contracts due to bribery of competitors, and the risk that bribery by representatives of the own organization is detected, bringing about potentially unknown costs. ${ }^{4}$ This can be seen as a tax on investment (Pellegrini and Gerlagh, 2004) or a discount on expected cash flows, which lowers the NPV of takeover synergies. As shown in Equation 1, the premium is normalized with the target's stand alone value. If corruption equally discounts all local NPVs, targets' stand alone values could decrease proportionally to the lower valuation of joint synergies. This would leave total returns to takeovers as well as premiums unchanged. However, this assumption does not necessarily apply. Mergers are, like other growth and expansion strategies, complex and risky projects. They often involve significant organizational, financial, and other business-related restructuring activities, including turnover among management and key employees, modifications of product portfolios, and changes in customer and/or supplier relations (see e.g. DePamphilis, 2005, pp.215). Stansbury (2005) reports that the size, uniqueness, and complexity of construction projects make them more susceptible to corruption than any other in the economy. Transferred to takeovers, it can be argued that the size, disruptive nature, and complexity of restructuring activities open up additional channels for bribery, allow to claim and hide bribes more effectively (Stansbury, 2005), and thus add uncertainty about possible detrimental effects of local corruption. When compared to the pre merger (stand alone) valuation of the target's running business, the impact of corruption as a discount factor may therefore be considered more important in the evaluation of merger synergies, constituting lower joint returns to mergers and a c.p. negative effect on target premiums. Moreover, with lower returns, deterred acquirers could increase the pressure on premiums even further. Hence, if the discount on synergies overcompensates possible distributional gains for the target as stipulated in Hypothesis 1a, we can formulate the following counter-hypothesis:

Hypothesis 1b: Target premiums and corruption of the host country are negatively related in cross-border takeovers.

\footnotetext{
4 This includes the costs that agreements based on corrupt activities are not fulfilled (since they are unenforceable), and the costs if such agreements are rendered null and void, which is possible in many countries if convincing proof is presented (Malta Conference, 1994).
} 
Since an increased uncertainty in corrupt host countries should affect all players in the market similarly, we do not expect that higher discounts on synergy valuations are restricted to crossborder takeovers only. Although domestic acquirers may be more familiar with local practices, the principal detrimental effect on target premiums should prevail (Habib and Zurawicki, 2002). As a robustness check we therefore predict that Hypothesis $1 \mathrm{~b}$ also holds for domestic acquisitions.

Figure 1 provides a summary over the argumentation for both hypotheses. Hypothesis 1a refers to a situation, where the 'pie of joint synergies' is assumed to be constant (upper solid line), while the target's share of synergies increases (upper dotted line). In contrast, Hypothesis $1 \mathrm{~b}$ assumes that the size of the pie that both parties bargain over (lower solid line) is negatively related to corruption, while the division of synergies between the two parties is fixed at a 50:50 ratio (lower dotted line).

\section{[ INSERT FIGURE 1 ABOUT HERE ]}

Prior studies on cross-border mergers have shown that greater cultural distance is positively associated with failure (Li and Guisinger, 1991), lower wealth effects (Datta and Puia, 1995), and additional challenges in post-merger integration (Chatterjee et al., 1992). It is thus reasonable to assume that takeover synergies are negatively related to the absolute difference between home and host country corruption. On the other hand, there also exists evidence that subsidiaries of MNEs that are headquartered in less corrupt countries, adapt very quickly to local corruptive practices (Kaufmann, 2004), which would imply no relation between differences in corruption and premiums.

Hypothesis 2b: Target premiums and the absolute difference of corruption between the home and the host country are either unrelated, or negatively related in cross-border takeovers.

\subsection{Corruption and related aspects of governance}

As Shleifer (2000, p.347f) commented on Wei (2000), “[v]arious measures of institutional quality, even when they come from different sources, and even when they address conceptually distinct aspects of the quality of government, are strongly positively correlated with each other." In analyzing corruption it is therefore crucial to consider other governancerelated variables, since these may explain very similar effects. Based on the pertinent literature on FDI, international M\&As and on determinants on the quality of government (La Porta et al., 1999), we suggest government effectiveness, political stability, as well as legal origins as a non-exhaustive list of governance features that are considered to be related with corruption and target premiums. Government effectiveness encompasses the competence of the bureaucracy and the quality of public service delivery. Political stability is defined as the 
inverse likelihood of violent threats to, or changes in, government, including terrorism. As legal origins we essentially distinguish essentially distinguish between two major legal traditions, common law and civil law.

\subsubsection{Government effectiveness}

In markets where excessive regulation impedes economic activity, some authors interpret bribes as a price paid for individual services, which re-establish market efficiency (see e.g. Leff, 1964; Huntington, 1968). As such, corruption is seen as 'grease': a Pareto-optimal response to graft around inefficient bureaucracy, taking the form of a semi-official fee collection system. ${ }^{5}$ However, corruption is likely to be determined endogenously, enabling rent-seeking bureaucrats to maximize payoffs by choosing an optimal level of rules, queuing procedures and administrative delay (Shleifer and Vishny, 1993; Kaufmann and Wei, 1999). In a general equilibrium, this leads to a nominal and effective increase in bureaucracy with corruption as 'sand' in the economy. Kaufmann and Wei (1999) show that managers are likely to spend more, not less, time and money when they engage in bribery. This may also be the reason why many firms, rank corruption and bureaucracy as key constraints to their business (Kaufmann, 2005).

Hypothesis 3: Target premiums and government effectiveness (host country) are positively related in cross-border takeovers.

Of course, bad governance and corruption are not the same - despite a common misunderstanding, which Kaufmann (2005) calls 'Myth \#1' about corruption. This also applies to distinct aspects of governance, like government effectiveness, as well as (discussed below) political stability, and legal origin. Although corruption is related to these variables, we would expect to see an additional effect on premiums.

Hypothesis 4: Corruption explains additional variation in target premiums of cross-border takeovers, after controlling for the individual effects of government effectiveness, political stability, and legal origin.

\subsubsection{Political stability}

Mo (2001) argues that corruption intensifies political instability through their effect on income polarization. Pellegrini and Gerlagh's (2004) provide evidence for this causality, using legal origins as instrumental variables. In the IB literature and also in Finance, the political stability of a host country is widely recognized as a critical determinant of investment decisions. Kobrin (1976), Habib and Zurawicki (2001), and Wei (2000a) report a positive correlation with FDI. Henisz (2000) provides evidence that politically less stable host

${ }^{5}$ For a more detailed discussion, see Bardhan (1997) as well as Kaufmann and Wei (1999). 
countries are more likely to attract joint ventures than majority owned plants. This suggests a positive association of political stability with takeover synergies and target premiums.

Hypothesis 5: Target premiums and political stability (host country) are positively related in cross-border takeovers.

\subsubsection{Legal origin}

La Porta et al. (1999, p.266) stress that "[1] egal origins remain extremely important factors shaping government performance." In comparative law, the discussion about the definition of legal families and general classification methods is ongoing (Mattei, 1997, 1999; Husa, 2001). Taking the more narrow perspective of commercial law, pertinent studies essentially distinguish between two major legal traditions, common law and civil law (Reuer et al., 2004; Rossi and Volpin, 2004; Glaeser and Shleifer, 2002; La Porta et al., 1998, p.1118), although different origins of the latter as well as religious influences can be identified (Zweigert and Kötz, 1998).

Along the lines of this basic distinction, Glaeser and Shleifer (2002) advance a theoretical model, which explains why common law provides a better legal environment for investor protection and why civil law can be associated with higher levels of corruption and red tape. Empirical evidence is consistent with these claims (La Porta et al., 1997, 1998, 1999; Djankov et al., 2002), which supports the inclusion of legal origin in Hypothesis 4.

Civil law origin is also found to be coupled with more ownership concentration and less developed capital markets, which may be interpreted as a response to weak shareholder protection (La Porta et al., 1998). Recently, La Porta et al. (2006) provided evidence that the financial disclosure standards may be the missing link to explain why common law, which puts more emphasis on market discipline and private litigation, is associated with better stock market development. Consistent with this, accounting standards and shareholder protection are positively related to stock market development (Pagano and Volpin, 2005), cross-border takeover activity and target premiums (Rossi and Volpin, 2004; La Porta et al., 2000, 2002).

Hypothesis 6: Target premiums and common (civil) law origin are positively (negatively) related in cross-border takeovers.

The inclusion of legal origin in our analysis serves two purposes. First, by employing legal origin (together with other variables related to shareholder protection) as a 'control' in the estimation of the relationship between corruption and premiums, we may be able to examine corruption more precisely as an own explanatory. Hypothesis 4 predicts that although corruption may be related to legal origin, it is nevertheless able to explain additional variation in premiums, effectively representing an idiosyncratic determinant in its own right. Second, a 
separate analysis of legal origin (Hypothesis 6), allows us to study, whether and how this related aspect of governance, in the presence of more specific variables for shareholder protection, i.e. accounting standards, financial disclosure, and ownership concentration, affects target premiums.

\section{Empirical specification and data}

\subsection{Model specification}

The baseline specification of the multivariate statistical models that we use to test the hypotheses is as follows:

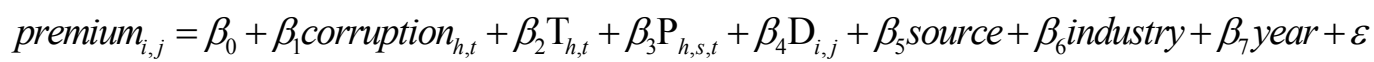

where $\mathrm{T}$ is a vector of the target's host country $(\mathrm{h})$ characteristics other than corruption and legal system in year $\mathrm{t}$; $\mathrm{P}$ is a vector of attributes specific to the acquirer-target country pair $(\mathrm{h}, \mathrm{s})$ in t; D is vector with deal specific characteristics of the takeover of target $\mathrm{i}$ by acquirer $\mathrm{j}$; source, industry, and year are dummy variables that take the value of one (and zero otherwise) to identify the (source) country of the acquirer, the industry of the acquirer, and the year of the acquisition announcement, respectively.

The source dummies are meant to capture the characteristics of the acquirer's home country (e.g. its size or level of economic development), since they are found to be related to a foreign firm's decision to take over a cross-border target (Anand and Kogut, 1997). This is a quasifixed regression similar to the model of Wei (2000), where the intercepts may vary depending on the acquirer's origin while no fixed effects are imposed on the host country (except in some rudimentary robustness checks). The latter would impair the estimation of effects that are specific to the target's local environment, including the country characteristics in vector T and other national parameters like corruption, government effectiveness, and political stability. However, since observations from the same host country are probably not independent from each other, in all regressions we correct for possible correlation by clustering at the target's country level according to Froot (1989) and Wooldridge (2002, section 13.8.2).

According to a number of IB studies the choice of entry and of diversification mode (Anand and Delios, 2002; Anand and Kogut, 1997), the merger performance (Dewenter, 1995; Markides and Ittner, 1994), as well as the contractual design of international takeovers (Reuer et al., 2004) differ across industries. Taking a transaction cost perspective, one of the main arguments is that firms in industries with more intangible assets are faced with greater contractual hazards when investing abroad (Henisz, 2000). In an attempt to control for these 
and other unobserved industry-specific effects, we include dummies for the acquirer's industry (one-digit SIC) in our econometric specification.

To control for time-related shocks across deals and countries, we also include year dummies.

Although monetary values (in US\$) are deflated with the US CPI (1982-1984=100) to prevent spurious trending due to inflation, we checked all estimations with an additional trend variable (unreported). ${ }^{6}$ It showed no significant effect and did not change results qualitatively. In all regressions, the reported standard errors are adjusted for heteroskedasticity, using the Huber (1967) and White (1980) sandwich estimator of variance.

\subsection{Choice of variables and measurements}

\subsubsection{Dependent variable}

The sole dependent variable is the takeover premium paid by the acquirer. The premium is calculated as the final bid price divided by the target share price closing one day before the announcement. This measurement corresponds to earlier studies on M\&A premiums (e.g. Rossi and Volpin, 2004; Officer, 2003). Since target premiums are known to be noisy we winzorise the data between $1 \%$ and $99 \%{ }^{7}$ In an attempt to minimize the influence of privatizations and of underdeveloped capital markets on our dependent variable, we do not compute premiums before 1996, where a number of transition economies conducted largescale privatization programs and also built up financial markets. In addition, in our analysis of premiums from 1996 to 2003, we control for state ownership of targets, as well as a number of other variables, which capture differences in stock market development and efficiency, e.g., capital market size, financial disclosure requirements, accounting standards, and ownership concentration.

\subsubsection{Independent variables}

Corruption: As the most important independent variable we use the Corruption Perceptions Index, which is published annually since 1996 by Transparency International (TI). The TI index assesses the degree to which public officials and politicians are believed to accept bribes or similar corruption related advantages. It incorporates 18 expert surveys conducted by 12 different organisations (status 2005) and is widely employed in various economic and business studies. $^{8}$ The original index is a continuous variable on a scale from 0 to 10 where 0

\footnotetext{
${ }^{6}$ Upon request, all unreported regressions mentioned in this paper are available from the authors.

${ }^{7}$ For a simlar procedure with the same database see e.g. Officer (2003) or Bates and Lemmon (2003).

${ }^{8}$ For an overview and a detailed discussion of the index (incl. a comparison with other measures of corruption), see Wei (2000), Husted (1999), Lambsdorff (1999).
} 
represents total corruption and 10 indicates no corruption at all. Since this is somewhat counter-intuitive we rescale the original index (by subtracting it from 10) so that a high score on the corruption index also represents a high level of corruption.

A similar index, which contains an even wider range of expert surveys (including all sources of the TI index), is published bi-annually since 1996 by The World Bank (WB). ${ }^{9}$ The WB index claims to measure the exercise of public power for private gain, including both petty and grand corruption, as well as state capture (Kaufmann et al., 2005). Due to the larger data base, the longer sub-periods, and a different composition technique, the WB index can cover more countries than the TI index, but this comes at the cost of larger cross-sectional margins of error (Kaufmann et al., 2004). The WB index measures control of corruption and ranges from -2.5 (no control) to +2.5 (full control). We multiply the original index with -1 so that our variable stays centralized, but increases in corruption.

Government Effectiveness: Together with the corruption index, The World Bank also publishes a bi-annual government effectiveness index (using the same methodology), which measures the competence of the bureaucracy and the quality of public service delivery (Kaufmann, 2005).

Political Stability: Together with the corruption index, The World Bank also publishes a biannual index of political stability and absence of violence (using the same methodology), which measures the inverse likelihood of violent threats to, or changes in, government, including terrorism.

Legal System: Unfortunately a number of important countries in our sample (e.g. in Eastern Europe) are not covered by La Porta's et al. (1998) taxonomy of legal origin. We therefore refer to a similar classification, which is published by the Faculty of Law of the University of Ontario. It covers most countries in the world by identifying influences of common or civil law, or both, sometimes with additional classifications into e.g. Muslim law, customary law, or mixed legal systems. We dummy the basic distinction between common/civil law origin, which turns out to capture the main effects (reported), while the inclusion of Muslim and customary law dummies (unreported) do not alter the results qualitatively.

\subsubsection{Control variables}

As specified in Equation (1) we include three categories of control variables to account for (a) characteristics of the target's country, (b) differences between the acquirer's and the target's country, as well as (c) firm and deal level determinants of the takeover itself. Here, we only

\footnotetext{
${ }^{9}$ See Kaufmann et al, 1999, 2002, 2004, and 2005.
} 
present the rationale for the choice of controls (variable names in italics). All details on the definition, calculation, and sources of the variables are presented in Table 1.

(a) A target's country characteristics may affect takeover premiums through different channels: potential synergies, takeover costs, or bidding competition. The level of potential synergies may be influenced by the absolute size of a country (Log of population), the wealth and purchasing power of its consumers (Log GDP per capita), or by GDP growth, which may have an impact on the anticipated cash flows of the target and the net present value of joint synergies (e.g. Rossi and Volpin, 2004; Henisz, 2000). ${ }^{10}$ The corporate tax level may also have a negative effect on potential synergies and premiums paid (Wei, 2000a), although better performing governments are found to collect higher taxes (La Porta et al., 1999). Takeover transaction costs may be influenced by the level of development of capital markets, which we proxy with their relative size in the economy (Capital market/GDP). In such markets, premiums may be lower due to higher costs of capital, less aggressive takeovers, and reduced bidding competition (Pagano and Volpin, 2005; Stulz, 2005). This may particularly apply to foreign bidding competition when restrictions are imposed on cross-border acquirers. We therefore include an indicator variable that identifies the existence of foreign ownership restrictions. Further, information asymmetries and uncertainty due to low levels of financial disclosure (Financ. disclosure), international comparability of accounting information (IFRS required), and corresponding shareholder protection may not only increase transaction costs and reduce M\&A activity (Pagano and Volpin, 2005; La Porta et al., 2006), but also lead to higher risk discounts and lower valuations of the target (La Porta et al., 2000, 2002).

Although a high level of ownership concentration can be interpreted as a reaction to weaker investor protection or financial disclosure, it may also deter hostile takeovers, reduce the number of bidders and premiums paid (La Porta et al., 1998). We expect that the combination of the above target country controls (particularly our proxies for capital market development, transparency, and host country wealth) also captures some cross-sectional variation in the local efficiency of valuations.

(b) When the acquirer comes from a substantially different cultural background than the target, this may increase transaction costs in post-merger integration. Many studies in M\&A point out that the integration of resources, particularly human resources, is critical for the success of acquisitions (DePamphilis,2005, p.31-21). High levels of cultural difference may increase post-merger management costs and lower the performance of acquisitions. Thus, the

\footnotetext{
${ }^{10}$ Where needed, monetary terms are deflated by the US CPI $(1982-1984=100)$ and a number of control variables are lagged by one year to prevent possible endogeneity (especially in small countries).
} 
greater the cultural distance, the more a foreign investor may prefer greenfield investments over mergers, suggesting less bidding competition and lower premiums. In fact, a number of studies find that cultural distance is associated with more greenfield investment (Kogut and Singh, 1988; Gatignon and Anderson, 1988, Chang and Rosenzweig, 2001). We therefore include power distance to control for this effect. ${ }^{11}$ If foreign acquirers want to reduce substantial transportation costs to the host country and/or bordering regions, large geographic distances may encourage market-oriented FDI to substitute (potential) exports (Brainard, 1997; Habib and Zurawicki, 2002). Everything else equal this would increase cross-border competition for the acquisition of local targets and positively impact premiums.. Interestingly, the inclusion of geographic distance may also serve as a partial explanation, why e.g. Australia, which is geographically relatively separated from major economies, ranks in our data as the fourth most popular host country for cross-border mergers (behind the US, UK, and Canada). Finally, exchange rate movements are likely to affect premiums. When the acquirer's home currency appreciates, the stand alone value of foreign targets in local currency decreases, which makes them cheaper to acquire (Harris and Ravenscraft, 1991; Markides and Ittner, 1994; Chang and Rosenzweig, 2001). This may increase the acquirer's willingness to pay higher target premiums in order to secure and swiftly close the deal in the face of (potential) bidder competition. We include the (lagged) change in the average annual exchange rates between the home/host countries of the merger, expressed in the target's home currency. A positive exchange rate movement thus represents a home (host) currency appreciation (depreciation).

(c) On the firm and deal level of the takeover, an extensive body of M\&A literature suggests to control for the following effects on target premiums. The percentage of payment in cash is found to generate higher returns to target shareholders (e.g. Andrade et al., 2001). The number of bidders and hostile takeovers can also be associated with higher premiums (Betton and Eckbo, 2000), although the evidence for hostile mergers is mixed (Schwert, 2000). Tender offers are positively related with premiums (Jensen and Ruback,1983; Jarell et al., 1988), while footholds (predbid ownership of target shares) reduce the probability of bidding competition and are negatively related to premiums (Betton and Eckbo, 2000). Futhermore, footholds may enable acquirers to gain more local experience and to alleviate possible market barrier effects of corruption, which makes it an interesting control variable for hypotheses 1a

\footnotetext{
${ }^{11}$ Since our model already includes a number of culture related variables (e.g. legal systems, corruption, disclosure, ownership) we use the Power Distance Index (PDI), being the strongest predictor within Hofstede’s (1980) cultural index (Husted, 1999), as a simple proxy.
} 
and 2a. Prior local investments in other targets may have a similar effect, as studies show that sequential FDI explains later entry modes (Chang and Rosenzweig, 2001). Other factors that may have an impact on target premiums may be the legal form of the acquirer (Public acquirer), the size of the takeover (i.e. target market value, as a proxy for complexity), and whether the deal is a privatization, which may capture special effects, like direct negotiations with possibly corrupt public bodies or the break-up of state monopolies. Finally, we also control for cross-border mergers in the same industry since these are usually more profitable (Gugler et al., 2003).

Given the large number of variables suggested by prior pertinent literature we had to make some choices. Based on the regression results with all control variables we tested more parsimonious models and found that an exclusion of the control variables ownership concentration, geographic distance, percentage of payment in cash, hostile takeover, and IFRS required (as alternative for financial disclosure) does not lead to qualitatively different results, since the explanatory effects of these controls are largely captured by other variables. Since space constraints forbid a presentation of the full model, we will discuss the slightly shortened version.

\section{[ INSERT TABLE 1 ABOUT HERE - OR IN SEPARATE APPENDIX]}

\subsection{Data set and descriptive findings}

\subsubsection{Sample design}

The regressions in this paper use takeover data with country-, year-, firm-, and deal-specific characteristics as well as macroeconomic country-year data. Both data types are combined into a single unbalanced panel by means of the year of the merger and of the countries involved. As mentioned above, our dependent variable ranges from 1996 to 2003. Fortunately this does not overly restrict other variables in our sample. Although the TI corruption index dates further back, the earliest governance indexes of The World Bank refer to 1996. Further, the availability of merger records in the SDC database significantly improved over the 90s, particularly with regard to non-OECD countries. ${ }^{12}$

To construct the sample we start with the SDC mergers and acquisitions database from Thomson Financial and extract all takeovers, which meet the following criteria: (1) the acquisition is announced between January 1, 1996 and December 31, 2003. (2) The acquisition is completed before October 31, 2005. (3) Acquirers hold less than $50 \%$ of target shares at announcement. (4) Acquirers hold more than 50\% of target shares after

\footnotetext{
${ }^{12}$ For 1990, SDC provides international coverage of 7144 transactions, including 396 transactions from non OECD countries (5.5\%). For 1999, 21881 transactions are recorded, including 3,300 from non-OECD countries (15\%).
} 
consummation. (5) The acquirer and the acquirer's ultimate parent are either both foreign (i.e. not incorporated in the target's host country) or both domestic. ${ }^{13}$ (6) Targets are publicly listed and no firm- or deal-specific variable mentioned in the preceding section is missing. After adding country-year data and winzorising the premium between $1 \%$ and $99 \%$ our sample consists of 42 countries with 4979 acquisitions, of which 961 are cross-border takeovers, and 4018 are domestic.

\section{[ INSERT TABLE 2 ABOUT HERE ]}

Table 2 (sorted by the number of total mergers) provides a summary of all countries in the sample and the country-year averages of the premiums as well as the most important governance variables. The top three countries in M\&A activity, the US, UK, and Japan, claim the vast majority of deals. In fact, over $75 \%$ of the whole sample includes takeovers that involve one of the three mentioned nations as the target's home country. ${ }^{14}$ To illustrate this in more detail, Figure 2 plots the premium and the annual TI corruption index of the target country for all 4979 takeovers. The fitted values for the US, UK and Japan (long dashes), and separately for the rest of the world (ROW, short dashes), show that the three most merger active nations have a steeper estimated relation between corruption and premiums. Note that this is a bivariate fit, which is not robust to multivariate specifications. As we will also see below this counter-intuitive fit is also a result of the high correlation between corruption and government effectiveness.

\section{[ INSERT FIGURE 2 ABOUT HERE ]}

In order to address these concerns about a possible sampling bias we will check our results in two ways. First, we repeat all regressions without the observations from the US, UK and Japan to test whether the general results are driven by these three countries. Since this selection is somewhat arbitrary we also estimate all regressions with inverse probability weighting (IPW). Here, each observation is weighted with the inverse of its probability that the observation is included due to the sampling design. Since we are interested in the effect of the target's country-specific characteristics on takeovers, we define this weight as the inverse of the number of mergers per country over all periods. This is in principle comparable to a regression across $n=42$ countries with aggregated values since country-specific characteristics

\footnotetext{
${ }^{13}$ By this we want to exclude mixed cases where foreign (direct) acquirers may execute decisions of their domestic parents and vice versa (see Shimizu et al, 2004, p.309).

14 The skewness of the distribution is similar to Gugler et al. (2003), who present a comprehensive international analysis of the SDC merger data.
} 
enter the regression with equal cross-sectional weights. However, a low number of aggregated observations would force us to omit a large number of variables. With IPW we have the advantage of added information across $n=4979$ takeovers, which also benefit us in the form of higher degrees of freedom. This enhances the comparability of results since we can leave the baseline specification of the different regressions unchanged.

\subsubsection{Variable description}

Table 3 reports the pairwise correlations for the most interesting variables in our model, the means and standard deviations for the full sample, as well as the means for domestic and for cross-border takeovers. In comparing the two sub samples we find a number of statistically significant but mostly moderate differences. ${ }^{15}$

The corruption indexes, and civil law are negatively related to the premium, while government effectiveness and common law show a positive statistical significance. The control variables (8-24) show no surprising signs. Of all significant control variables, GDP per capita reports the highest pairwise correlation with independent variables. As expected, financial disclosure, capital market size, and corporate taxes are substantially related to the domestic legal origin.

\section{[ INSERT TABLE 3 ABOUT HERE ]}

As mentioned in the generation of the hypotheses, one of the problems with measures of quality of governance is that they are strongly correlated with each other. In Table 3 this is reflected in moderate to high correlation values between most governance-related variables (2-7). When we test the multicollinearity among corruption and all other control variables (824) using the variance-inflation factor (VIF), the TI (WB) corruption index has a value of 3.46 (3.25). Of all variables only financial disclosure $(5.88,5.81$, respectively) has a somewhat higher value than 5.3 (cut-off point according to Hair et al. (1992)). However, when we include other governance-related independent variables, maximum VIF values come close to or even reach 10 (cut-off according to Belsley, Kuh, \& Welsch (1980), and Studenmund (1992)).

In principle such collinearity between corruption and other governance variables does not bias the OLS, although it inflates variation within the model and increases the danger of type II errors (false negative) with regard to the variable we are primarily interested in (Wooldridge, 2003, p.96). We will therefore insert all governance-related variables individually, but also try combinations with corruption to investigate, which variable is still able to explain some of the

\footnotetext{
${ }^{15}$ Noteworthy exceptions are that the cross-border sample contains a politically more unstable environment $(+81 \%$ compared to domestic mean), a higher proportion of civil law legal systems $(+73 \%)$, and more tender offers $(+79 \%)$.
} 
remaining variation. Thus, in some of our specifications, we rather accept that the real influence of corruption is (falsely) inferred as statistically insignificant, than risk a possible bias due to omitted (governance-related) variables.

\section{Results}

\subsection{Cross-border mergers and corruption}

Table 4 presents the results of several OLS regression models that are used to test Hypotheses $1 \mathrm{a} / \mathrm{b}$ and $2 \mathrm{a} / \mathrm{b}$. Model 1 and 2 are our baseline regressions with the complete panel of crossborder takeovers including all control variables plus the TI and WB corruption indexes, respectively. Both models support Hypothesis $1 \mathrm{~b}$ and explain 17\% of target premiums. Most of the coefficients of the control variables show the expected signs. Note that the corporate tax level of the target country is positively correlated with premiums, which is consistent with La Porta's et al. (1999) argument of better performing governments. Since the average percentage of cash in cross-border considerations is $75 \%$, the level of corporate taxes may, alternatively, also proxy the additional tax burden of target shareholders, which they are likely to at least partially transfer to acquirers when the premium constitutes a taxable event (i.e. when payment is in cash and not in stock). Further, GDP per capita reports a negative coefficient, which may reflect lower growth prospects of wealthier nations, especially since past GDP growth seems to be significantly (positively) related with the size of premiums. ${ }^{16}$ As robustness check Model 3 and 4 use a panel without targets from the US, UK, and Japan (no UUJ), while regressions in Model 5 and 6 use inverse probability weights (IPW). ${ }^{17}$ All models support Hypothesis $1 \mathrm{~b}$ (and the $\mathrm{R}^{2}$ increases to $26-31 \%$ ), but it is interesting to see that the economic and statistical significance of corruption decreases when countries with more takeover activity are either excluded (no UUJ) or enter the estimation with less weight (IPW). This can be interpreted as an indication that the corruption variable also proxies other effects. In Model 7 (Baseline), and in Model 8 to 10 (IPW) the absolute difference of corruption between home and host countries is added. ${ }^{18}$ Although the absolute difference has a negative sign, which would support Hypothesis $2 b$, it is not significant. This even holds when we remove the dummies for the acquirer's home country (Model 9 and 10), since they

\footnotetext{
${ }^{16}$ In support of this explanation, Table 3 reports a negative bivariate correlation between past GDP growth and GDP per capita.

${ }^{17}$ In Model 3 and 4 a total of 547 takeovers with targets from the US, UK, or Japan are excluded.

${ }^{18}$ The number of observations decreases slightly since some acquirer countries have no TI and/or WB corruption index, which is needed for computing an absolute difference.
} 
may capture some of the country differences we are interested in. We also tried other (unreported) combinations with the corruption indexes, country dummies, the IPW method, and the panel without US/UK/Japan, but they did not alter the basic result. Another indication that market barriers to entry do not play a dominant role for foreign acquirers in determining takeover premiums, is the fact that neither footholds, nor prior local investment experience show a significant effect. Model 11 to 14 (DOM and D-IPW) repeat the regressions of Model 1, 2, 5, and 6 respectively, but with 4016 domestic instead of 961 cross-border takeovers. ${ }^{19}$ As mentioned in the theoretical section, we use the domestic setting as a robustness check for Hypotheses $1 \mathrm{~b}$ and 2a. In support of Hypothesis 1b, we mostly find a significant negativerelationship between the level of corruption and target premiums in domestic mergers. Again, unreported robustness checks with the exclusion of US, UK, and Japanese takeovers confirm this result. This clearly corroborates the notion of corruption as a discount on merger synergies, but not as market barriers to entry. As discussed earlier, the IPW models are quite comparable across the two panels, since they reduce sampling effects at the host country level. Here, it is interesting to see that domestic acquirers seem to have some advantages over foreign investors, since the economic and statistical significance of the WB corruption index in Model 14 is distinctly lower than in the corresponding cross-border Model 6 (while the effect of the TI index practically remains unchanged). In summary, we find that Hypotheses $1 b$ and $2 b$ are supported. This corroborates the theoretical notion that negative effects of uncertainty overcompensate possible positive market barrier effects, such that an increase in the level of host country corruption is associated with lower and not higher premiums. A caveat about this result is that we can not clearly distinguish between the effects of higher discounts (lower synergies) and those of deterred foreign acquirers. Also, although we attempt to control for differences in the efficiency of valuations across countries (with proxies for e.g. capital market development, transparency, and local wealth), we naturally can not exclude that some of the reported effects contain variations in asset valuation capabilities.

\section{[ INSERT TABLE 4 ABOUT HERE ]}

\subsection{Cross-border mergers and related aspects of governance}

Table 5 presents the results of several OLS regression models that are used to test Hypotheses 3 to 6. In support of Hypothesis 3, Model 1 reports a positive association of premiums with government effectiveness. As predicted by Hypothesis 4, the level of corruption is still able to explain additional variation in the model, even after correcting for government effectiveness (Model 2). However, this does not apply anymore, when we either exclude the three most

\footnotetext{
${ }^{19}$ We removed the acquirer's country dummy since it represents a host country fixed effect in the domestic panel.
} 
active takeover nations (unreported) or use inverse probability weights (reported in IPWModel 3). Thus, Hypothesis 4 is not fully supported. In fact, both variables 'neutralize' each other due to their high multicollinearity $(\beta=0.83 ; \mathrm{p}<0.01)$ and their effects turn out to explain target premiums more or less equally good or bad. Interestingly, we do not find this with any other governance-related variable, as the rest of the models show. As predicted, common law is positively associated with premiums (Model 4 and 5), while civil law reports a negative correlation (Model 6). However, either legal origin is only significant when financial disclosure is omitted, which has a high bivariate correlation with common law $(\beta=0.73$; $\mathrm{p}<0.01)$ and with civil law $(\beta=-0.76 ; \mathrm{p}<0.01)$. Since financial disclosure standards are stronger in common law countries and considered to be a key element in a country's financial development (La Porta et al., 2006), we are inclined to interpret these results as moderate support for Hypothesis 6. This also applies to Hypothesis 4, which we consider largely supported by Model 7 and 8. All results of Model 4 to 8 hold when we correct for other legal systems like Muslim law or customary law. On the basis of Hypothesis 5 we expect to see a positive relation of political stability with takeover premiums. However, the results of Model 9 show a negative, albeit non-significant, coefficient, which becomes statistically significant once the TI corruption index is inserted (Model 10). Despite numerous checks and alternative specifications this counter-intuitive result stayed remarkably robust. ${ }^{20}$ However, we find that political stability is associated with wealthy $(\beta=0.4 ; \mathrm{p}<0.01)$ and financially developed $(\beta=0.14 ; p<0.01)$ countries, which are typically also very active in takeovers. Consequently, a reduction of these sampling influences in Model 11 (IPW) also reduces the significance of political stability. Although corruption explains additional variance and although Hypothesis 4 is again supported, these results require further inspection for possible explanations. In summary we find strong support for Hypothesis 3, and moderate support for Hypotheses 4 and 6. Thus, government effectiveness, and to a lesser extent legal origin, are identified as predictors of target premiums. Further, our findings on corruption are robust to the inclusion of governance-related variables, except government effectiveness. The results reported in Table 5 remain qualitatively unchanged when we either, exclude the US, UK, and Japan, or estimate with IPW. The only exceptions are two special cases, which we report for IPW (Model 3 and 11), but which also apply to the exclusion of the US, UK, and Japan. The presented results do not change qualitatively when we replace the TI corruption index with the WB index, although some coefficients turn out to be less significant.

\footnotetext{
${ }^{20} \mathrm{We}$, inter alia, omitted Israel as an outlier, analyzed several interaction effects, checked different samples, various time lags, absolute differences, and various fixed effects specifications.
} 


\section{[ INSERT TABLE 5 ABOUT HERE ]}

\section{Discussion and Conclusion}

This study analyzed the relationship between corruption, related variables of governance, and premiums paid by foreign and domestic acquirers for taking control of local corporate assets. The analysis provides evidence that local shareholder wealth that is lost due to corruption. Generally, the findings in this paper add depth to our understanding of the familiar negative relationship between FDI and corruption, as we show that it not just reflects lower aggregate flows, but substantially reduced valuations for assets. In this sense, the familiar negative relationship for FDI at least partially reflects the value lost to domestic asset holders due to corruption. In the following the most important findings and their implications for managers and policy makers are presented in more detail.

\section{A higher level of corruption in the host country is associated with lower target premiums.}

This central finding is relatively robust with regard to different samples and measures of corruption. On the basis of the literature this implies that higher uncertainty in corrupt host countries and corresponding valuation discounts overcompensate possible market barrier effects, where the domestic target might have a stronger bargaining position or more interested foreign bidders, due to its position as an insider. For decision making in international takeovers, this result also shows that the level of corruption in the host country constitutes an important component in the estimation of joint synergies and target prices. However, as discussed below, this also holds for government ineffectiveness, which may explain some counter-intuitive results for highly active takeover markets.

Local corruption barely gives domestic acquirers an edge over foreign bidders. Although we find evidence that domestic acquirers are somewhat less affected by their country's level of corruption, probably due to their greater knowledge of local practices, in general, this advantage does not render corruption irrelevant. In fact, with one of the corruption indexes (TI) we barely observe any difference between foreign and domestic takeovers. Consequently, managers of domestic acquirers can, on average, not assume that they enjoy a serious advantage over foreign investors with regard to insights into local systems of corruption. Corruption matters. The costs associated with corruption in cross-border and domestic takeovers are substantial. A deterioration in the host country corruption index (TI) by one point (on a ten point scale) is, on average, associated with a decrease of $3.52 \%$ to $6.28 \%$ of a cross-border target's ratio of bid price to stand-alone value, depending on the sample studied (see Model 1, 3, and 5 in Table 4). Using the average premium of the cross-border sample (30.6\%), armchair calculations suggest that target shareholders lose at best $15 \%$ and at worst 
$26.8 \%$ of their premium, with an average reduction of $20.9 \%$. This is associated with a jump of one point in the TI index, which is equivalent to the difference in the levels of corruption between Hungary (4.8) and the Czech Republic (5.88), Spain (3.46) and Slovenia (4.53), or South Korea (5.82) and Mexico (6.85) (see Table 2).

Corruption measures provide additional information for target premium estimations when compared to political stability and legal origin. Although a number of other aspects related to governance either include corruption or capture similar effects, none of them seems to fully substitute the specific nature of corruption. This finding supports many scholars and policy makers, who rate the fight against corruption as a key element to welfare and economic development (Kaufmann and Kraay, 2002), while acknowledging the importance of other aspects of governance.

In cross-border takeover premiums, the corruption index seems to primarily capture the effects of government ineffectiveness (and vice versa), supporting the notion of endogeneity between bribery and red tape. Although both corruption indexes (TI and WB) add some additional explanatory power (see Model 2 in Table 5 for the TI measure), the general impression across a whole range of regressions is that their large multicollinearity with government effectiveness $(\beta=-0.83$ for TI and $\beta=-0.91$ for WB; $p<0.01$ ) stretch the search for idiosyncratic variation to the limit. In fact, particularly for countries with relatively little corruption, it is very well possible that the higher annual variance of the TI corruption index captures some latent effects of the less time-sensitive bi-annual index for government ineffectiveness. This may be a reason for the counter-intuitive bivariate fit in Figure 2, although it is probably only a partial explanation, since the bi-annual WB index is also significant $(\beta=-0.12 ; \mathrm{p}<0.05)$ when it replaces the TI index in Model 2 (Table 5).

The close relationship between government effectiveness and corruption may indicate that the traditional notion of corruption, which mainly captures outright bribery of public officials, is too narrow; particularly for financially and economically more developed countries. This may be seen as a limitation of this paper. Recent attempts challenge the conventional definition of corruption as 'abuse of public power for private gain' and propose broader measures, including vested interests, influence peddling, and outright capture of the elite (Kaufmann, 2004). Based on the literature on agency costs and entrenchment in takeovers, a wider measurement and definition of corruption, could also allow studying corruption between private parties (MacRae, 1982), i.e. between acquirers and targets directly.

Another limitation of this study is that we identify corruption and government effectiveness as significant determinants in cross-border takeovers, but do not analyze causality. However, 
disentangling these influences is a complex task, since most instruments for corruption, such as legal systems or other governance related variables, have the power to forecast nearly all aspects of institutional quality and are therefore problematic (see also Shleifer 2000).

Addressing the above limitations would be an important task for future research. 


\section{Tables and Figures}

Figure 1: Joint takeover synergies, their division between targets and acquirers, and corruption

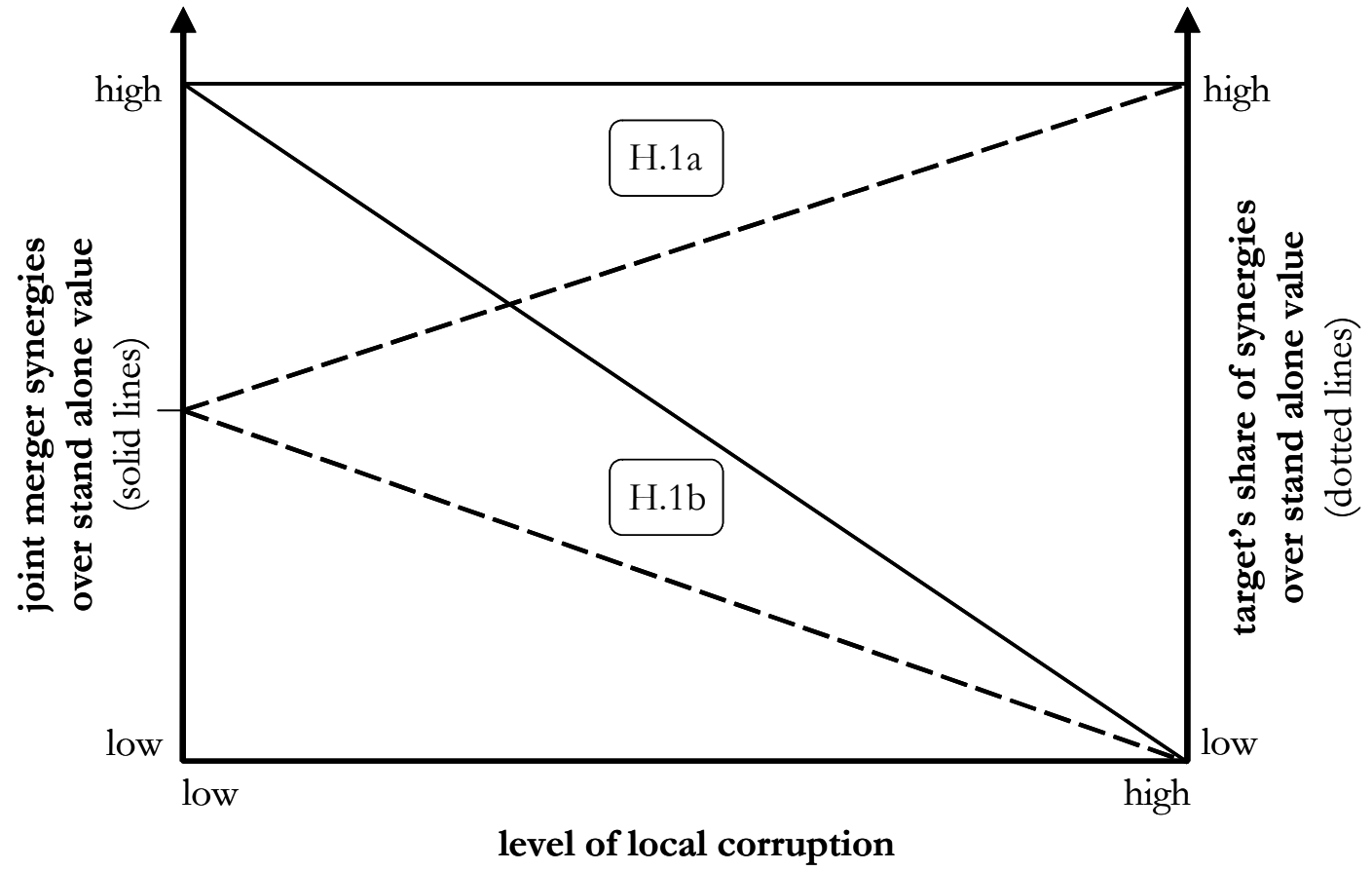

Figure 2: Target premiums and TI corruption index of total sample 


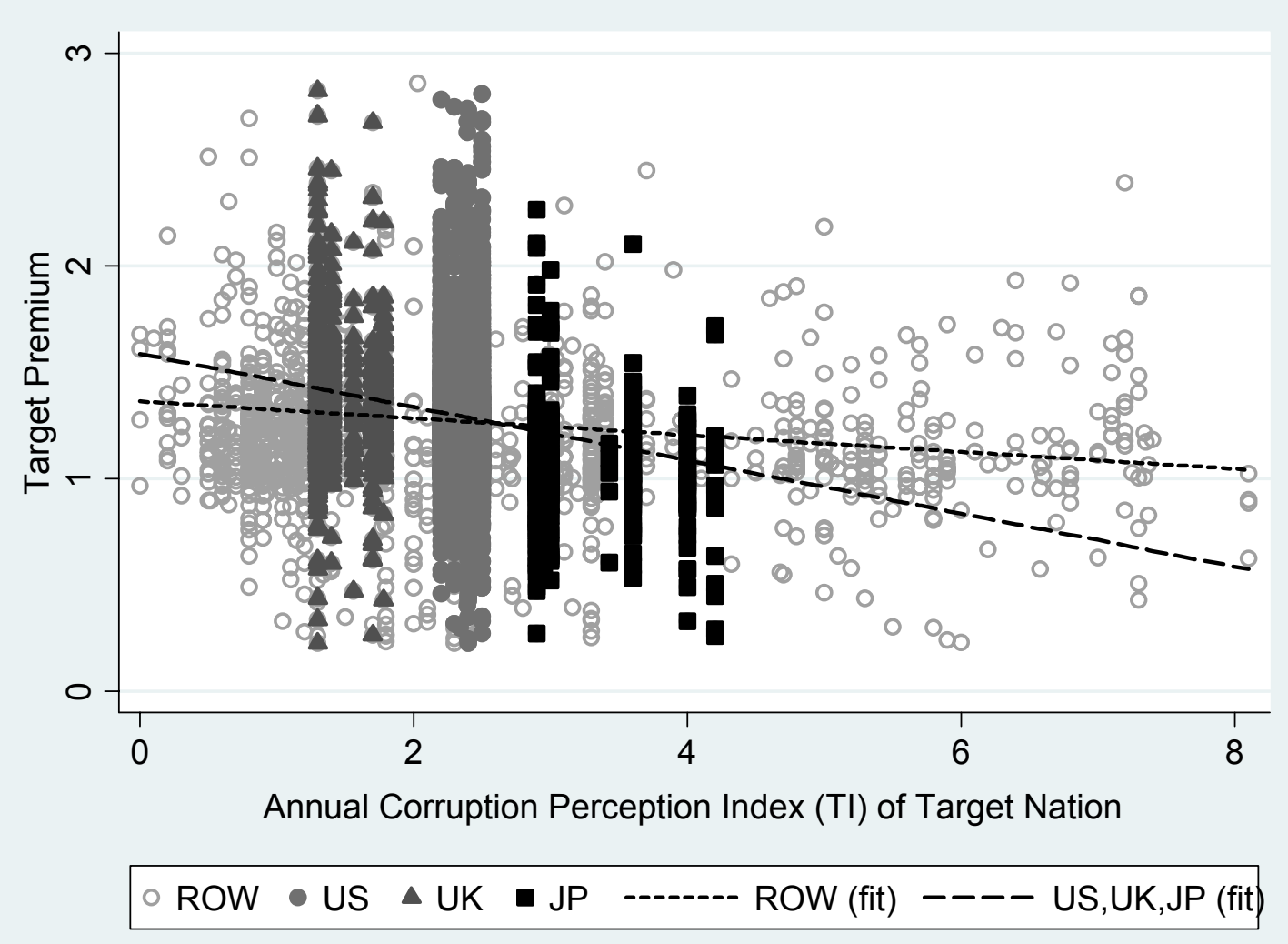

Table 1: Variable description and sources

\begin{tabular}{|l|l|}
\hline Variable & Description and source \\
\hline Premium & $\begin{array}{l}\text { Share price paid by the acquirer divided by the target share price } \\
\text { closing one day before the announcement (winzorised between 1\% and } \\
99 \%) \text {. Source: SDC Thomson. }\end{array}$ \\
\hline Corruption TI & $\begin{array}{l}\text { Corruption perception index (CPI) from Transparency International } \\
\text { (TI). We subtract the original index from 10 so that our variable } \\
\text { increases in corruption, i.e. from 0 (no corruption) to 10 (completely } \\
\text { corrupt). Source: http://www.transparency.org }\end{array}$ \\
\hline Corruption WB & $\begin{array}{l}\text { Control of corruption index published by The World Bank. The } \\
\text { original index ranges from }-2.5 \text { (no control) to }+2.5 \text { (full control). We } \\
\text { multiply it with }-1 \text { so that our variable increases in corruption. Source: } \\
\text { Kaufmann et al. (2005) }\end{array}$ \\
\hline Gov. effectiveness & $\begin{array}{l}\text { Government effectiveness index published by The World Bank. The } \\
\text { index ranges from }-2.5 \text { to }+2.5 . \text { Source: Kaufmann et al. (2005) }\end{array}$ \\
\hline Political stability & $\begin{array}{l}\text { Index of political stability and absence of violence published by The } \\
\text { World Bank. The index ranges from }-2.5 \text { to }+2.5 \text { (fully effective). }\end{array}$ \\
\hline
\end{tabular}




\begin{tabular}{|c|c|}
\hline & Source: Kaufmann et al. (2005) \\
\hline Common law & $\begin{array}{l}\text { Indicator variable equal to } 1 \text { if legal origin is (also) common law. } \\
\text { Source: University of Ottawa, Faculty of Law, World Legal Systems, } \\
\text { www.droitcivil.uottawa.ca }\end{array}$ \\
\hline Civil law & $\begin{array}{l}\text { Indicator variable equal to } 1 \text { if legal origin is (also) civil law. Source: } \\
\text { University of Ottawa, Faculty of Law, World Legal Systems, } \\
\text { www.droitcivil.uottawa.ca }\end{array}$ \\
\hline Log GDP per capita & $\begin{array}{l}\text { Natural logarithm of the annual Gross Domestic Product, deflated by } \\
\text { the US CPI }(1982 / 84=100) \text {, and divided by population, lagged by } 1 \\
\text { year. Source: World Development Indicators } 2005 \text {, The World Bank. }\end{array}$ \\
\hline GDP change & $\begin{array}{l}\text { Annual growth rate of the Gross Domestic Product, deflated by the US } \\
\text { CPI }(1982 / 84=100) \text {, lagged by } 1 \text { year. Source of GDP: World } \\
\text { Development Indicators } 2005 \text {, The World Bank. }\end{array}$ \\
\hline Log of population & $\begin{array}{l}\text { Natural logarithm of annual population. Source: World Development } \\
\text { Indicators 2005, The World Bank. }\end{array}$ \\
\hline Exch.rate movement & $\begin{array}{l}\text { Lagged change in the average annual currency exchange rates (t-2 to t- } \\
\text { 1) between the host (target) and home (acquirer) country, expressed in } \\
\text { the target country's currency. Source: World Development Indicators } \\
\text { 2005, The World Bank. }\end{array}$ \\
\hline Geograph. distance & $\begin{array}{l}\text { Great circle distance between capital cities in kilometres. Source: } \\
\text { Gleditsch and Ward, } 2001\end{array}$ \\
\hline Power distance & $\begin{array}{l}\text { Power distance index (PDI), measured on a scale from } 0-100 . \text { We } \\
\text { compute the absolute difference between the home and host country's } \\
\text { PDI as simple proxy for cultural difference (mean substitution for } \\
\text { missing values). Source: www.geert-hofstede.com. }\end{array}$ \\
\hline Capital market/GDP & $\begin{array}{l}\text { Annual stock market capitalization as percentage of GDP, lagged by } 1 \\
\text { year. Source: World Development Indicators } 2005 \text {, World Bank. }\end{array}$ \\
\hline Financ. disclosure & $\begin{array}{l}\text { Index for the level of financial disclosure standards in the host country } \\
\text { (mean substitution for missing values). Source: La Porta et al., } 2006 \text {. }\end{array}$ \\
\hline IFRS required & $\begin{array}{l}\text { Indicator variable equal to } 1 \text { if the International Financial Reporting } \\
\text { Standards (IFRS) are required for all domestic listed companies. } \\
\text { Australia, New Zealand, Hong Kong, Philippines, Singapore, USA are } \\
\text { coded 1, due to comparable accounting transparency (Pacter, 2005). } \\
\text { Source: Deloitte Touche Tohmatsu, www.iasplus.com (Dec. 08, 2005) }\end{array}$ \\
\hline
\end{tabular}




\begin{tabular}{|c|c|}
\hline Ownership concentr & $\begin{array}{l}\text { Index for the concentration of ownership in the host country (mean } \\
\text { substitution for missing values). Source: La Porta et al. (1998) }\end{array}$ \\
\hline Ownership restrict & $\begin{array}{l}\text { Indicator variable equal to } 1 \text { if the country is reported to have } \\
\text { ownership restrictions for foreign investors. Source: Wei (2000) }\end{array}$ \\
\hline Corporate tax & $\begin{array}{l}\text { Total amount of taxes (in host country) that a medium-size company } \\
\text { must pay or withhold in a given year, as a share of gross profit. Source: } \\
\text { Doing Business, The World Bank, 2005. www.doingbusiness.org }\end{array}$ \\
\hline Target market val & $\begin{array}{l}\text { Natural logarithm of the market value of the target } 4 \text { weeks prior to the } \\
\text { bid (in real million US\$, deflated by US CPI }(1982 / 84=100) \text { ). Source: } \\
\text { SDC Thomson. }\end{array}$ \\
\hline Privatization & $\begin{array}{l}\text { Indicator variable equal to } 1 \text { if the government is the majority owner of } \\
\text { the target. Source: SDC Thomson. }\end{array}$ \\
\hline Payment in cash & Percentage of consideration paid in cash. Source: SDC Thomson. \\
\hline Tender offer & $\begin{array}{l}\text { Indicator variable equal to } 1 \text { if the takeover is consummated via tender } \\
\text { offer. Source: SDC Thomson. }\end{array}$ \\
\hline Hostile & $\begin{array}{l}\text { Indicator variable equal to } 1 \text { if the target's board officially rejects the } \\
\text { takeover bid. Source: SDC Thomson. }\end{array}$ \\
\hline Number of bidders & Number of bidders in a takeover contest. Source: SDC Thomson. \\
\hline Same industry & $\begin{array}{l}\text { Indicator variable equal to } 1 \text { if target and acquirer share the same } 4 \\
\text { digit SIC code. Source: SDC Thomson. }\end{array}$ \\
\hline Public acquirer & $\begin{array}{l}\text { Indicator variable equal to } 1 \text { if the acquirer is a publicly listed } \\
\text { company. Source: SDC Thomson. }\end{array}$ \\
\hline Foothold & $\begin{array}{l}\text { Indicator variable equal to } 1 \text { if the acquirer holds up to } 49 \% \text { of the } \\
\text { target at the time of the announcement of the takeover. Source: SDC } \\
\text { Thomson. }\end{array}$ \\
\hline Prior local invest & $\begin{array}{l}\text { Indicator variable equal to } 1 \text { if the acquirer took over an other target in } \\
\text { the host country within } 3 \text { years prior to the merger announcement. } \\
\text { Source: SDC Thomson. }\end{array}$ \\
\hline acq. ctry dum. & $\begin{array}{l}67 \text { minus } 1 \text { dummies specifying the acquirer's home country. Source: } \\
\text { SDC Thomson. }\end{array}$ \\
\hline indstr dum. & $\begin{array}{l}9 \text { minus } 1 \text { dummies specifying the acquirer's primary line of business } \\
\text { (1 digit SIC). Source: SDC Thomson. }\end{array}$ \\
\hline year dum. & $\begin{array}{l}8 \text { minus } 1 \text { dummies specifying the year of the takeover announcement. } \\
\text { Source: SDC Thomson. }\end{array}$ \\
\hline
\end{tabular}


Table 2: Takeovers, average premiums, and independent variables per country

\begin{tabular}{|c|c|c|c|c|c|c|c|c|c|c|}
\hline Country & \#MA all & $\begin{array}{l}\text { \#MA } \\
\text { cross- } \\
\text { border }\end{array}$ & $\begin{array}{c}\# \mathrm{MA} \\
\text { domes- } \\
\text { tic } \\
\end{array}$ & $\begin{array}{c}\text { Target } \\
\text { premi- } \\
\text { um } \\
\end{array}$ & $\begin{array}{c}\text { Corrup- } \\
\text { tion TI } \\
\end{array}$ & $\begin{array}{l}\text { Corrup- } \\
\text { tion WB }\end{array}$ & $\begin{array}{c}\text { Gov. } \\
\text { Effective- } \\
\text { ness }\end{array}$ & $\begin{array}{c}\text { Politic } \\
\text { Stabi- } \\
\text { lity } \\
\end{array}$ & $\begin{array}{l}\text { Com- } \\
\text { mon } \\
\text { Law } \\
\end{array}$ & $\begin{array}{l}\text { Civil } \\
\text { Law } \\
\end{array}$ \\
\hline UNITED STATES & 2867 & 357 & 2510 & 1.31 & 2.39 & -1.8 & 1.76 & 0.86 & 1 & 0 \\
\hline UNITED KINGDOM & 659 & 178 & 481 & 1.36 & 1.44 & -2.15 & 2.13 & 0.96 & 1 & 0 \\
\hline JAPAN & 265 & 12 & 253 & 1.05 & 3.27 & -1.26 & 1.12 & 1.15 & 1 & 1 \\
\hline AUSTRALIA & 198 & 50 & 148 & 1.2 & 1.37 & -2.01 & 1.82 & 1.19 & 1 & 0 \\
\hline CANADA & 182 & 55 & 127 & 1.2 & 0.94 & -2.29 & 1.98 & 1.14 & 1 & 0 \\
\hline FRANCE & 136 & 45 & 91 & 1.17 & 3.32 & -1.47 & 1.52 & 0.86 & 0 & 1 \\
\hline HONG KONG & 82 & 21 & 61 & 0.92 & 2.21 & -1.51 & 1.43 & 0.99 & 1 & 0 \\
\hline SWEDEN & 66 & 30 & 36 & 1.28 & 0.71 & -2.38 & 1.82 & 1.44 & 0 & 1 \\
\hline NORWAY & 47 & 29 & 18 & 1.29 & 1.11 & -2.11 & 1.72 & 1.46 & 0 & 1 \\
\hline GERMANY & 44 & 16 & 28 & 1.14 & 2.3 & -1.85 & 1.74 & 1.2 & 0 & 1 \\
\hline SINGAPORE & 43 & 14 & 29 & 1.23 & 0.83 & -2.39 & 2.35 & 1.4 & 1 & 0 \\
\hline SOUTH AFRICA & 41 & 11 & 30 & 1.15 & 5.04 & -0.46 & 0.4 & -0.35 & 1 & 1 \\
\hline NETHERLANDS & 40 & 23 & 17 & 1.28 & 1.09 & -2.28 & 2.14 & 1.44 & 0 & 1 \\
\hline ITALY & 35 & 7 & 28 & 1.07 & 5.27 & -0.79 & 0.79 & 0.77 & 0 & 1 \\
\hline SPAIN & 24 & 4 & 20 & 1.16 & 3.46 & -1.47 & 1.64 & 0.8 & 0 & 1 \\
\hline INDIA & 22 & 6 & 16 & 1.19 & 7.23 & 0.24 & -0.1 & -0.55 & 1 & 0 \\
\hline IRELAND & 21 & 12 & 9 & 1.27 & 2.47 & -1.71 & 1.77 & 1.38 & 1 & 0 \\
\hline NEW ZEALAND & 21 & 10 & 11 & 1.27 & 0.57 & -2.3 & 1.76 & 1.34 & 1 & 0 \\
\hline DENMARK & 20 & 7 & 13 & 1.4 & 0.28 & -2.34 & 1.94 & 1.32 & 0 & 1 \\
\hline MALAYSIA & 16 & 3 & 13 & 1.13 & 4.89 & -0.32 & 0.87 & 0.54 & 1 & 0 \\
\hline SWITZERLAND & 16 & 6 & 10 & 0.98 & 1.22 & -2.23 & 2.25 & 1.63 & 0 & 1 \\
\hline THAILAND & 15 & 4 & 11 & 1.1 & 6.81 & 0.22 & 0.25 & 0.31 & 1 & 1 \\
\hline KOREA, SOUTH & 13 & 3 & 10 & 0.91 & 5.82 & -0.32 & 0.74 & 0.41 & 0 & 1 \\
\hline FINLAND & 12 & 9 & 3 & 1.29 & 0.27 & -2.49 & 2 & 1.65 & 0 & 1 \\
\hline BELGIUM & 11 & 4 & 7 & 1.31 & 3.58 & -1.32 & 1.51 & 0.94 & 0 & 1 \\
\hline GREECE & 11 & 3 & 8 & 0.98 & 5.58 & -0.63 & 0.77 & 0.76 & 0 & 1 \\
\hline PHILIPPINES & 10 & 2 & 8 & 1.48 & 6.81 & 0.5 & 0.06 & -0.4 & 1 & 1 \\
\hline POLAND & 10 & 10 & 0 & 1.07 & 5.83 & -0.44 & 0.52 & 0.81 & 0 & 1 \\
\hline CHILE & 7 & 6 & 1 & 1.26 & 3.19 & -1.39 & 1.33 & 0.79 & 0 & 1 \\
\hline HUNGARY & 7 & 4 & 3 & 1.16 & 4.8 & -0.65 & 0.78 & 0.88 & 0 & 1 \\
\hline AUSTRIA & 6 & 2 & 4 & 1.31 & 2.43 & -1.99 & 1.62 & 1.41 & 0 & 1 \\
\hline ISRAEL & 6 & 3 & 3 & 1.47 & 2.9 & -1.17 & 1.01 & -0.74 & 0 & 1 \\
\hline CZECH REPUBLIC & 5 & 4 & 1 & 1.33 & 5.88 & -0.38 & 0.7 & 0.9 & 0 & 1 \\
\hline INDONESIA & 5 & 2 & 3 & 0.92 & 7.95 & 1.02 & -0.43 & -1.03 & 0 & 1 \\
\hline SLOVENIA & 4 & 1 & 3 & 1.08 & 4.53 & -0.98 & 0.82 & 1.08 & 0 & 1 \\
\hline MEXICO & 4 & 1 & 3 & 1.4 & 6.85 & 0.33 & 0.21 & -0.03 & 0 & 1 \\
\hline CROATIA & 2 & 1 & 1 & 1.15 & 6.2 & -0.12 & 0.18 & 0.47 & 0 & 1 \\
\hline LITHUANIA & 2 & 2 & 0 & 0.98 & 5.9 & -0.27 & 0.38 & 0.43 & 0 & 1 \\
\hline ARGENTINA & 1 & 1 & 0 & 1.31 & 7 & 0.36 & 0.3 & 0.46 & 0 & 1 \\
\hline BOLIVIA & 1 & 1 & 0 & 1.01 & 6.6 & 0.81 & -0.49 & -0.28 & 0 & 1 \\
\hline GHANA & 1 & 1 & 0 & 1.69 & 6.7 & 0.17 & -0.17 & -0.1 & 1 & 0 \\
\hline LATVIA & 1 & 1 & 0 & 1.07 & 6.6 & -0.09 & 0.67 & 0.82 & 0 & 1 \\
\hline
\end{tabular}


Table 3: Pairwise correlation, means, and standard deviation

\begin{tabular}{|c|c|c|c|c|c|c|c|c|c|c|c|c|c|c|c|c|c|c|c|c|c|c|c|c|c|}
\hline & $\mathrm{n}$ & 1 & 2 & 3 & 4 & 5 & 6 & 7 & 8 & 9 & 10 & 11 & 12 & 13 & 14 & 15 & 16 & 17 & 18 & 19 & 20 & 21 & 22 & 23 & 24 \\
\hline 1) Target premium & 4979 & 1 & & & & & & & & & & & & & & & & & & & & & & & \\
\hline 2) Corruption $\mathrm{TI}$ & 4979 & $-0.12^{*}$ & 1 & & & & & & & & & & & & & & & & & & & & & & \\
\hline 3) Corruption WB & 4979 & $-0.14^{*}$ & $0.91^{*}$ & 1 & & & & & & & & & & & & & & & & & & & & & \\
\hline 4) Gov. effectiveness & 4979 & $0.17^{*}$ & $-0.83^{*}$ & $-0.91^{*}$ & 1 & & & & & & & & & & & & & & & & & & & & \\
\hline 5) Polit. stability & 4979 & -0.02 & $-0.47^{*}$ & $-0.49^{*}$ & $0.43^{*}$ & 1 & & & & & & & & & & & & & & & & & & & \\
\hline 6) Common law & 4979 & $0.08^{*}$ & $-0.15^{*}$ & $-0.14^{*}$ & $0.2^{*}$ & $-0.08^{*}$ & 1 & & & & & & & & & & & & & & & & & & \\
\hline 7) Civil law & 4979 & $-0.17^{*}$ & $0.38^{*}$ & $0.43^{*}$ & $-0.52^{*}$ & 0.02 & $-0.76^{*}$ & 1 & & & & & & & & & & & & & & & & & \\
\hline 8) Log GDP per capita & 4979 & $0.07^{*}$ & $-0.53^{*}$ & $-0.59^{*}$ & $0.56^{*}$ & $0.4^{*}$ & $0.18^{*}$ & $-0.26^{*}$ & 1 & & & & & & & & & & & & & & & & \\
\hline 9) GDP change & 4979 & $0.07^{*}$ & $-0.08^{*}$ & $-0.15^{*}$ & $0.21^{*}$ & $0.24^{*}$ & $0.07^{*}$ & $-0.33^{*}$ & $-0.04 *$ & 1 & & & & & & & & & & & & & & & \\
\hline 10) Log of population & 4979 & $0.11^{*}$ & $0.3^{*}$ & $0.15^{*}$ & $-0.06^{*}$ & $-0.23^{*}$ & $0.47^{*}$ & $-0.4^{*}$ & $0.3^{*}$ & 0.02 & 1 & & & & & & & & & & & & & & \\
\hline 11) Exch.rate movement & 4979 & 0 & $0.05^{*}$ & $0.06^{*}$ & $-0.07^{*}$ & -0.02 & $-0.07^{*}$ & $0.09^{*}$ & $-0.09^{*}$ & -0.03 & $-0.06^{*}$ & 1 & & & & & & & & & & & & & \\
\hline 12) Power distance abs & 4979 & 0.02 & $0.06^{*}$ & $0.08^{*}$ & $-0.08^{*}$ & 0 & $-0.2^{*}$ & $0.15^{\star}$ & $-0.18^{*}$ & $0.04^{*}$ & $-0.19^{*}$ & $-0.14^{*}$ & 1 & 1 & & & & & & & & & & & \\
\hline 13) Capital market/GDP & 4979 & $0.09^{*}$ & $-0.28^{*}$ & $-0.24^{*}$ & $0.35^{*}$ & $-0.14^{*}$ & $0.34^{*}$ & $-0.44^{*}$ & $0.21^{*}$ & $0.16^{*}$ & $0.08^{*}$ & $-0.08^{*}$ & ${ }^{*}-0.04^{*}$ & 1 & & & & & & & & & & & \\
\hline 14) Financ. disclosure & 4979 & $0.12^{*}$ & & $-0.09^{*}$ & $0.18^{*}$ & $-0.15^{*}$ & $0.73^{*}$ & $-0.76^{*}$ & $0.31^{*}$ & $0.2^{*}$ & $0.73^{*}$ & $-0.07^{*}$ & ${ }^{*}-0.18^{*}$ & * $0.36^{*}$ & 1 & & & & & & & & & & \\
\hline 15) Corporate tax & 4979 & 0 & $-0.16^{*}$ & $-0.1^{*}$ & $0.07^{*}$ & $0.08^{*}$ & $-0.49^{*}$ & $0.47^{*}$ & $-0.34^{*}$ & $-0.14^{*}$ & $-0.62^{*}$ & $0.04^{*}$ & ${ }^{*} 0.15^{*}$ & * $-0.21^{*}$ & $-0.8^{*}$ & 1 & & & & & & & & & \\
\hline 16) Ownership restrict & 4979 & $-0.06^{*}$ & $0.04^{*}$ & $0.08^{*}$ & $-0.12^{*}$ & $-0.08^{*}$ & $-0.09^{*}$ & $0.05^{*}$ & $-0.4^{*}$ & $0.05^{*}$ & $-0.23^{*}$ & 0.02 & $0.04^{*}$ & ${ }^{*}-0.21^{*}$ & $-0.12^{*}$ & $0.08^{*}$ & 1 & & & & & & & & \\
\hline 17) Target market val & 4979 & $-0.07^{*}$ & 0.02 & -0.02 & 0.03 & $0.11^{*}$ & $-0.1^{*}$ & $0.04^{*}$ & $0.06^{*}$ & $0.08^{*}$ & $0.05^{*}$ & -0.01 & $0.06^{*}$ & * $-0.07^{*}$ & -0.02 & -0.02 & 0.01 & 1 & & & & & & & \\
\hline 18) Privatization & 4979 & $-0.05^{*}$ & $0.15^{*}$ & $0.13^{*}$ & $-0.12^{*}$ & $-0.04^{*}$ & $-0.1^{*}$ & $0.09^{*}$ & $-0.13^{*}$ & 0 & $-0.07^{*}$ & -0.02 & & $0-0.08^{*}$ & $-0.08^{*}$ & $0.05^{*}$ & $0.06^{*}$ & $0.05^{*}$ & 1 & & & & & & \\
\hline 19) Tender offer & 4979 & $0.12^{*}$ & $-0.25^{*}$ & $-0.22^{*}$ & $0.22^{*}$ & $0.15^{\star}$ & $-0.14^{*}$ & $0.05^{*}$ & $-0.12^{*}$ & $0.04^{*}$ & $-0.36^{*}$ & -0.01 & $0.12^{*}$ & * 0.01 & $-0.33^{*}$ & $0.47^{*}$ & $0.04^{*}$ & -0.03 & 0 & 1 & & & & & \\
\hline 20) Number of bidders & 4979 & $0.08^{*}$ & $-0.06^{*}$ & $-0.06^{*}$ & $0.04^{*}$ & 0.02 & -0.02 & -0.02 & -0.02 & 0.02 & $-0.07^{*}$ & $-0.05^{\star}$ & ${ }^{*} 0.05^{*}$ & ${ }^{*}-0.05^{*}$ & $-0.05^{*}$ & $0.06^{*}$ & $0.06^{*}$ & $0.09^{*}$ & & $0.11^{*}$ & 1 & & & & \\
\hline 21) Same industry & 4979 & 0.01 & 0.01 & 0 & -0.01 & -0.02 & 0.01 & -0.01 & -0.02 & 0.02 & 0.01 & 0 & -0.01 & $1-0.07^{*}$ & 0.02 & -0.03 & $0.05^{*}$ & $0.1^{*}$ & 0.02 & $-0.05^{*}$ & 0.01 & 1 & & & \\
\hline 22) Public acquirer & 4979 & 0.03 & 0.02 & -0.01 & 0 & $0.04^{*}$ & $0.09^{*}$ & $-0.04^{*}$ & $0.09^{*}$ & 0.03 & $0.18^{*}$ & & $-0.05^{*}$ & * $-0.1^{*}$ & $0.12^{*}$ & $-0.14^{*}$ & 0.02 & $0.19^{*}$ & -0.02 & $-0.15^{*}$ & ${ }^{*}-0.04^{*}$ & $0.17^{*}$ & 1 & & \\
\hline 23) Foothold & 4979 & $-0.12^{*}$ & $0.14^{*}$ & $0.2^{*}$ & $-0.22^{*}$ & -0.01 & $-0.17^{*}$ & $0.32^{*}$ & $-0.19^{*}$ & $-0.16^{*}$ & $-0.25^{*}$ & -0.01 & $0.11^{*}$ & * $-0.09^{*}$ & $-0.29^{*}$ & $0.18^{*}$ & $0.04^{*}$ & $-0.04^{*}$ & 0.01 & $0.09^{*}$ & ${ }^{*}-0.01$ & $-0.07^{*}$ & $-0.13^{*}$ & 1 & \\
\hline 24) Prior local invest & 4979 & $-0.06^{*}$ & $0.05^{*}$ & $0.08^{*}$ & $-0.09^{*}$ & 0.01 & $-0.08^{*}$ & $0.11^{*}$ & $-0.07^{*}$ & $-0.05^{*}$ & $-0.12^{*}$ & 0.01 & 0.02 & $2-0.02$ & $-0.1^{*}$ & 0.03 & 0.01 & 0 & $0.06^{*}$ & -0.02 & 0 & -0.01 & -0.03 & 0.03 & 1 \\
\hline mean & 4979 & 1.27 & 2.31 & -1.79 & 1.73 & 0.98 & 0.89 & 0.17 & 10.18 & 3.27 & 18.57 & -0.22 & 2.07 & 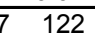 & 0.9 & 30.7 & 0.06 & 4.69 & 0 & 0.39 & 1.05 & 0.31 & 0.74 & 0.16 & 0.03 \\
\hline s.d. & 4979 & 0.33 & 1 & 0.43 & 0.37 & 0.38 & 0.31 & 0.38 & 0.5 & 1.58 & 1.22 & 4.02 & 7.02 & $2 \quad 49.7$ & 0.14 & 13.2 & 0.24 & 1.85 & 0.07 & 0.49 & 0.26 & 0.46 & 0.44 & 0.37 & 0.17 \\
\hline mean (domestic) & 4018 & $1.26^{*}$ & $2.34^{*}$ & $-1.78^{*}$ & $1.72^{*}$ & $0.97^{*}$ & $0.92^{*}$ & $0.15^{*}$ & $10.21 *$ & $3.21^{*}$ & $18.72^{*}$ & $0^{*}$ & $0^{*}$ & * 122.7 & $0.92^{*}$ & $29.4^{*}$ & $0.05^{*}$ & $4.58^{*}$ & 0 & $0.34^{*}$ & $1.05^{*}$ & 0.31 & 0.73 & $0.15^{*}$ & 0.03 \\
\hline mean (cross border) & 961 & $1.31^{*}$ & $2.18^{*}$ & $-1.83^{*}$ & $1.76^{*}$ & $1.76^{*}$ & $0.77^{*}$ & $0.26^{*}$ & $10.05^{*}$ & $3.5^{\star}$ & $17.95^{*}$ & $-1.12^{*}$ & * $10.7^{*}$ & * 119.0 & $0.84^{*}$ & $36.5^{*}$ & $0.09^{*}$ & $5.14^{*}$ & 0.01 & $0.61^{*}$ & $1.07^{*}$ & 0.32 & 0.75 & $0.2^{*}$ & 0.02 \\
\hline
\end{tabular}

significant at $1 \%$ 
Table 4: Target premium (dependent) and corruption

\begin{tabular}{|c|c|c|c|c|c|c|c|c|c|c|c|c|c|c|}
\hline Variable & 1: Base & 2: Base & 3: no UUJ & 4: no UUJ & 5: IPW & 6: IPW & 7: Base & 8: IPW & 9: IPW & 10: IPW & 11: Dom. & 12: Dom. & 13: D-IPW & 14: D-IPW \\
\hline Corruption TI & $\begin{array}{l}-0.0628 \\
{[3.56]^{\star \star *}}\end{array}$ & & $\begin{array}{l}-0.0471 \\
{[2.98]^{\star \star \star}}\end{array}$ & & $\begin{array}{l}-0.0352 \\
{[2.34]^{* *}}\end{array}$ & & $\begin{array}{l}-0.0589 \\
{[3.26]^{\star * *}}\end{array}$ & $\begin{array}{l}-0.0279 \\
{[1.70]^{*}}\end{array}$ & $\begin{array}{l}-0.0405 \\
{[2.37]^{\star *}}\end{array}$ & & $\begin{array}{l}-0.0472 \\
{[3.06]^{\star \star \star}}\end{array}$ & & $\begin{array}{l}-0.0386 \\
{[2.60]^{\star *}}\end{array}$ & \\
\hline Corruption WB & & $\begin{array}{l}-0.1353 \\
{[2.77]^{\star \star *}}\end{array}$ & & $\begin{array}{l}-0.1071 \\
{[2.39]^{\star *}}\end{array}$ & & $\begin{array}{l}-0.071 \\
{[1.99]^{*}}\end{array}$ & & & & $\begin{array}{l}-0.0865 \\
{[2.04]^{* *}}\end{array}$ & & $\begin{array}{l}-0.1303 \\
{[2.83]^{\star \star *}}\end{array}$ & & $\begin{array}{l}-0.0326 \\
{[0.78]}\end{array}$ \\
\hline Corr TI diff abs & & & & & & & $\begin{array}{l}-0.006 \\
{[0.41]}\end{array}$ & $\begin{array}{l}-0.0168 \\
{[1.02]}\end{array}$ & $\begin{array}{l}-0.0202 \\
{[1.36]}\end{array}$ & & & & & \\
\hline Corr WB diff abs & & & & & & & & & & $\begin{array}{l}-0.0424 \\
{[1.11]}\end{array}$ & & & & \\
\hline Log GDP per capita & $\begin{array}{l}-0.0681 \\
{[2.03]^{* *}}\end{array}$ & $\begin{array}{l}-0.063 \\
{[1.94]^{*}}\end{array}$ & $\begin{array}{l}-0.0641 \\
{[1.80]^{*}}\end{array}$ & $\begin{array}{l}-0.0656 \\
{[1.91]^{*}}\end{array}$ & $\begin{array}{l}-0.0277 \\
{[0.73]}\end{array}$ & $\begin{array}{l}-0.0227 \\
{[0.64]}\end{array}$ & $\begin{array}{l}-0.0671 \\
{[1.94]^{*}}\end{array}$ & $\begin{array}{l}-0.0323 \\
{[0.87]}\end{array}$ & $\begin{array}{l}-0.0643 \\
{[1.91]^{*}}\end{array}$ & $\begin{array}{l}-0.0632 \\
{[2.04]^{\star *}}\end{array}$ & $\begin{array}{l}-0.0228 \\
{[0.70]}\end{array}$ & $\begin{array}{l}-0.0388 \\
{[1.05]}\end{array}$ & $\begin{array}{l}-0.0644 \\
{[2.05]^{* *}}\end{array}$ & $\begin{array}{l}-0.0347 \\
{[0.94]}\end{array}$ \\
\hline GDP change & $\begin{array}{l}0.0264 \\
{[2.86]^{\star * *}}\end{array}$ & $\begin{array}{l}0.0255 \\
{[2.75]^{\star \star \star}}\end{array}$ & $\begin{array}{l}0.0278 \\
{[2.62]^{\star *}}\end{array}$ & $\begin{array}{l}0.0266 \\
{[2.52]^{\star *}}\end{array}$ & $\begin{array}{l}0.0081 \\
{[0.87]}\end{array}$ & $\begin{array}{l}0.0074 \\
{[0.79]}\end{array}$ & $\begin{array}{l}0.0262 \\
{[2.83]^{\star \star \star}}\end{array}$ & $\begin{array}{l}0.0069 \\
{[0.72]}\end{array}$ & $\begin{array}{l}0.0095 \\
{[1.10]}\end{array}$ & $\begin{array}{l}0.0092 \\
{[1.03]}\end{array}$ & $\begin{array}{l}0.0016 \\
{[0.22]}\end{array}$ & $\begin{array}{l}0.0008 \\
{[0.11]}\end{array}$ & $\begin{array}{l}-0.0052 \\
{[0.75]}\end{array}$ & $\begin{array}{l}-0.0046 \\
{[0.61]}\end{array}$ \\
\hline Log of population & $\begin{array}{l}0.0486 \\
{[2.71]^{* * *}}\end{array}$ & $\begin{array}{l}0.04 \\
{[2.24]^{\star *}}\end{array}$ & $\begin{array}{l}0.0197 \\
{[1.22]}\end{array}$ & $\begin{array}{l}0.0131 \\
{[0.86]}\end{array}$ & $\begin{array}{l}0.0129 \\
{[0.67]}\end{array}$ & $\begin{array}{l}0.0108 \\
{[0.57]}\end{array}$ & $\begin{array}{l}0.0475 \\
{[2.64]^{* *}}\end{array}$ & $\begin{array}{l}0.0125 \\
{[0.67]}\end{array}$ & $\begin{array}{l}0.0092 \\
{[0.46]}\end{array}$ & $\begin{array}{l}0.0049 \\
{[0.26]}\end{array}$ & $\begin{array}{l}0.0611 \\
{[5.17]^{* * *}}\end{array}$ & $\begin{array}{l}0.0581 \\
{[4.49]^{\star * *}}\end{array}$ & $\begin{array}{l}-0.0051 \\
{[0.24]}\end{array}$ & $\begin{array}{l}-0.014 \\
{[0.65]}\end{array}$ \\
\hline Exch.rate movement & $\begin{array}{l}0.0023 \\
{[1.92]^{*}}\end{array}$ & $\begin{array}{l}0.0024 \\
{[2.00]^{*}}\end{array}$ & $\begin{array}{l}-0.001 \\
{[0.34]}\end{array}$ & $\begin{array}{l}-0.0009 \\
{[0.33]}\end{array}$ & $\begin{array}{l}-0.004 \\
{[1.18]}\end{array}$ & $\begin{array}{l}-0.0038 \\
{[1.11]}\end{array}$ & $\begin{array}{l}0.0021 \\
{[1.72]^{*}}\end{array}$ & $\begin{array}{l}-0.0045 \\
{[1.27]}\end{array}$ & $\begin{array}{l}-0.0048 \\
{[1.73]^{*}}\end{array}$ & $\begin{array}{l}-0.004 \\
{[1.51]}\end{array}$ & & & & \\
\hline Power distance abs & $\begin{array}{l}-0.0001 \\
{[0.14]}\end{array}$ & $\begin{array}{l}-0.0003 \\
{[0.32]}\end{array}$ & $\begin{array}{l}0.0008 \\
{[0.63]}\end{array}$ & $\begin{array}{l}0.0007 \\
{[0.56]}\end{array}$ & $\begin{array}{l}0.0026 \\
{[1.84]^{*}}\end{array}$ & $\begin{array}{l}0.0028 \\
{[1.98]^{*}}\end{array}$ & $\begin{array}{l}0 \\
{[0.00]}\end{array}$ & $\begin{array}{l}0.0027 \\
{[1.85]^{*}}\end{array}$ & $\begin{array}{l}0.0028 \\
{[1.64]}\end{array}$ & $\begin{array}{l}0.0034 \\
{[1.99]^{\star}}\end{array}$ & & & & \\
\hline Capital market/GDP & $\begin{array}{l}-0.0004 \\
{[1.12]}\end{array}$ & $\begin{array}{l}-0.0004 \\
{[0.90]}\end{array}$ & $\begin{array}{l}-0.0006 \\
{[1.27]}\end{array}$ & $\begin{array}{l}-0.0005 \\
{[1.08]}\end{array}$ & $\begin{array}{l}-0.0007 \\
{[1.32]}\end{array}$ & $\begin{array}{l}-0.0006 \\
{[1.16]}\end{array}$ & $\begin{array}{l}-0.0004 \\
{[1.15]}\end{array}$ & $\begin{array}{l}-0.0006 \\
{[1.28]}\end{array}$ & $\begin{array}{l}-0.0009 \\
{[1.78]^{*}}\end{array}$ & $\begin{array}{l}-0.0008 \\
{[1.49]}\end{array}$ & $\begin{array}{l}0.0002 \\
{[0.68]}\end{array}$ & $\begin{array}{l}0.0002 \\
{[0.84]}\end{array}$ & $\begin{array}{l}-0.0001 \\
{[0.35]}\end{array}$ & $\begin{array}{l}0.0001 \\
{[0.18]}\end{array}$ \\
\hline Financ. disclosure & $\begin{array}{l}0.3844 \\
{[2.65]^{\star *}}\end{array}$ & $\begin{array}{l}0.4074 \\
{[2.87]^{\star * *}}\end{array}$ & $\begin{array}{l}0.2451 \\
{[1.19]}\end{array}$ & $\begin{array}{l}0.2697 \\
{[1.33]}\end{array}$ & $\begin{array}{l}0.4216 \\
{[2.16]^{* *}}\end{array}$ & $\begin{array}{l}0.4345 \\
{[2.26]^{* *}}\end{array}$ & $\begin{array}{l}0.3867 \\
{[2.65]^{\star *}}\end{array}$ & $\begin{array}{l}0.4157 \\
{[2.14]^{* *}}\end{array}$ & $\begin{array}{l}0.3929 \\
{[1.73]^{*}}\end{array}$ & $\begin{array}{l}0.3698 \\
{[1.76]^{*}}\end{array}$ & $\begin{array}{l}0.1792 \\
{[1.54]}\end{array}$ & $\begin{array}{l}0.1505 \\
{[1.35]}\end{array}$ & $\begin{array}{l}0.1438 \\
{[0.86]}\end{array}$ & $\begin{array}{l}0.2195 \\
{[1.22]}\end{array}$ \\
\hline Ownership restrict & $\begin{array}{l}-0.0462 \\
{[0.99]}\end{array}$ & $\begin{array}{l}-0.0366 \\
{[0.78]}\end{array}$ & $\begin{array}{l}-0.0084 \\
{[0.18]}\end{array}$ & $\begin{array}{l}-0.0028 \\
{[0.06]}\end{array}$ & $\begin{array}{l}0.1287 \\
{[1.82]^{\star}}\end{array}$ & $\begin{array}{l}0.1326 \\
{[1.93]^{*}}\end{array}$ & $\begin{array}{l}-0.0414 \\
{[0.91]}\end{array}$ & $\begin{array}{l}0.1399 \\
{[2.02]^{*}}\end{array}$ & $\begin{array}{l}0.1215 \\
{[1.69]^{*}}\end{array}$ & $\begin{array}{l}0.1148 \\
{[1.72]^{*}}\end{array}$ & & & & \\
\hline Corporate tax & $\begin{array}{l}0.0056 \\
{[4.55]^{\text {}}}\end{array}$ & $\begin{array}{l}0.0057 \\
{[4.57]^{\star * *}}\end{array}$ & $\begin{array}{l}0.0048 \\
{[1.70]^{*}}\end{array}$ & $\begin{array}{l}0.0051 \\
{[1.78]^{*}}\end{array}$ & $\begin{array}{l}0.0055 \\
{[2.43]^{* *}}\end{array}$ & $\begin{array}{l}0.0057 \\
{[2.50]^{* *}}\end{array}$ & $\begin{array}{l}0.0056 \\
{[4.46]^{* * *}}\end{array}$ & $\begin{array}{l}0.0057 \\
{[2.60]^{* *}}\end{array}$ & $\begin{array}{l}0.0045 \\
{[2.02]^{* *}}\end{array}$ & $\begin{array}{l}0.0043 \\
{[1.95]^{*}}\end{array}$ & $\begin{array}{l}0.0019 \\
{[1.92]^{*}}\end{array}$ & $\begin{array}{l}0.0014 \\
{[1.38]}\end{array}$ & $\begin{array}{l}0.0047 \\
{[1.49]}\end{array}$ & $\begin{array}{l}0.0058 \\
{[1.70]^{*}}\end{array}$ \\
\hline Target market val & $\begin{array}{l}-0.0169 \\
{[1.99]^{*}}\end{array}$ & $\begin{array}{l}-0.0169 \\
{[1.98]^{*}}\end{array}$ & $\begin{array}{l}-0.0164 \\
{[1.04]}\end{array}$ & $\begin{array}{l}-0.0168 \\
{[1.07]}\end{array}$ & $\begin{array}{l}0.0076 \\
{[0.53]}\end{array}$ & $\begin{array}{l}0.0072 \\
{[0.50]}\end{array}$ & $\begin{array}{l}-0.0173 \\
{[2.06]^{\star *}}\end{array}$ & $\begin{array}{l}0.0063 \\
{[0.44]}\end{array}$ & $\begin{array}{l}0.0118 \\
{[0.88]}\end{array}$ & $\begin{array}{l}0.0119 \\
{[0.91]}\end{array}$ & $\begin{array}{l}-0.0164 \\
{[1.95]^{\star}}\end{array}$ & $\begin{array}{l}-0.0169 \\
{[2.08]^{\star *}}\end{array}$ & $\begin{array}{l}0.006 \\
{[0.75]}\end{array}$ & $\begin{array}{l}0.006 \\
{[0.75]}\end{array}$ \\
\hline Privatization & $\begin{array}{l}0.0794 \\
{[0.55]}\end{array}$ & $\begin{array}{l}0.0671 \\
{[0.47]}\end{array}$ & $\begin{array}{l}-0.0152 \\
{[0.08]}\end{array}$ & $\begin{array}{l}-0.0302 \\
{[0.17]}\end{array}$ & $\begin{array}{l}0.0597 \\
{[0.38]}\end{array}$ & $\begin{array}{l}0.0576 \\
{[0.36]}\end{array}$ & $\begin{array}{l}0.071 \\
{[0.49]}\end{array}$ & $\begin{array}{l}0.0501 \\
{[0.30]}\end{array}$ & $\begin{array}{l}0.0756 \\
{[0.44]}\end{array}$ & $\begin{array}{l}0.0565 \\
{[0.35]}\end{array}$ & $\begin{array}{l}-0.1116 \\
{[1.85]^{\star}}\end{array}$ & $\begin{array}{l}-0.1288 \\
{[2.19]^{\star *}}\end{array}$ & $\begin{array}{l}-0.1423 \\
{[1.66]}\end{array}$ & $\begin{array}{l}-0.1587 \\
{[1.87]^{*}}\end{array}$ \\
\hline Tender offer & $\begin{array}{l}0.0572 \\
{[1.89]^{*}}\end{array}$ & $\begin{array}{l}0.0594 \\
{[1.96]^{*}}\end{array}$ & $\begin{array}{l}0.0852 \\
{[2.31]^{\star *}}\end{array}$ & $\begin{array}{l}0.0867 \\
{[2.38]^{* *}}\end{array}$ & $\begin{array}{l}0.1065 \\
{[1.95]^{*}}\end{array}$ & $\begin{array}{l}0.1099 \\
{[2.01]^{*}}\end{array}$ & $\begin{array}{l}0.0637 \\
{[2.24]^{* *}}\end{array}$ & $\begin{array}{l}0.1104 \\
{[2.00]^{*}}\end{array}$ & $\begin{array}{l}0.12 \\
{[2.16]^{* *}}\end{array}$ & $\begin{array}{l}0.1331 \\
{[2.43]^{* *}}\end{array}$ & $\begin{array}{l}0.0882 \\
{[4.06]^{* * *}}\end{array}$ & $\begin{array}{l}0.0869 \\
{[3.99]^{* * *}}\end{array}$ & $\begin{array}{l}0.0342 \\
{[0.65]}\end{array}$ & $\begin{array}{l}0.0373 \\
{[0.71]}\end{array}$ \\
\hline Number of bidders & $\begin{array}{l}0.0926 \\
{[3.27]^{\star * *}}\end{array}$ & $\begin{array}{l}0.0923 \\
{[3.24]^{\star * \star}}\end{array}$ & $\begin{array}{l}0.084 \\
{[1.76]^{*}}\end{array}$ & $\begin{array}{l}0.0835 \\
{[1.76]^{*}}\end{array}$ & $\begin{array}{l}0.0297 \\
{[0.52]}\end{array}$ & $\begin{array}{l}0.0296 \\
{[0.51]}\end{array}$ & $\begin{array}{l}0.0937 \\
{[3.50]^{\star \star \star}}\end{array}$ & $\begin{array}{l}0.0322 \\
{[0.57]}\end{array}$ & $\begin{array}{l}0.071 \\
{[1.16]}\end{array}$ & $\begin{array}{l}0.0668 \\
{[1.09]}\end{array}$ & $\begin{array}{l}0.1075 \\
{[6.55]^{\star \star *}}\end{array}$ & $\begin{array}{l}0.1066 \\
{[6.50]^{\star \star \star}}\end{array}$ & $\begin{array}{l}0.0767 \\
{[1.56]}\end{array}$ & $\begin{array}{l}0.0802 \\
{[1.66]}\end{array}$ \\
\hline Same industry & $\begin{array}{l}0.0418 \\
{[3.20]^{* * *}}\end{array}$ & $\begin{array}{l}0.0415 \\
{[3.24]^{* * *}}\end{array}$ & $\begin{array}{l}0.0333 \\
{[1.21]}\end{array}$ & $\begin{array}{l}0.0321 \\
{[1.15]}\end{array}$ & $\begin{array}{l}0.0425 \\
{[0.66]}\end{array}$ & $\begin{array}{l}0.0432 \\
{[0.67]}\end{array}$ & $\begin{array}{l}0.0444 \\
{[3.32]^{* \star *}}\end{array}$ & $\begin{array}{l}0.0386 \\
{[0.60]}\end{array}$ & $\begin{array}{l}0.0354 \\
{[0.65]}\end{array}$ & $\begin{array}{l}0.0297 \\
{[0.57]}\end{array}$ & $\begin{array}{l}0.0072 \\
{[1.05]}\end{array}$ & $\begin{array}{l}0.0069 \\
{[0.97]}\end{array}$ & $\begin{array}{l}0.071 \\
{[1.01]}\end{array}$ & $\begin{array}{l}0.0766 \\
{[1.07]}\end{array}$ \\
\hline Public acquirer & $\begin{array}{l}0.0743 \\
{[2.71]^{\star \star *}}\end{array}$ & $\begin{array}{l}0.0761 \\
{[2.72]^{\star \star \star}}\end{array}$ & $\begin{array}{l}0.0856 \\
{[1.93]^{\star}}\end{array}$ & $\begin{array}{l}0.0879 \\
{[1.95]^{*}}\end{array}$ & $\begin{array}{l}0.1124 \\
{[2.31]^{\star *}}\end{array}$ & $\begin{array}{l}0.1123 \\
{[2.30]^{* *}}\end{array}$ & $\begin{array}{l}0.08 \\
{[2.96]^{\star \star \star}}\end{array}$ & $\begin{array}{l}0.1187 \\
{[2.48]^{* *}}\end{array}$ & $\begin{array}{l}0.1079 \\
{[2.15]^{\star *}}\end{array}$ & $\begin{array}{l}0.1046 \\
{[2.12]^{\star *}}\end{array}$ & $\begin{array}{l}0.0148 \\
{[1.68]}\end{array}$ & $\begin{array}{l}0.0167 \\
{[1.84]^{*}}\end{array}$ & $\begin{array}{l}-0.018 \\
{[0.56]}\end{array}$ & $\begin{array}{l}-0.0173 \\
{[0.52]}\end{array}$ \\
\hline Foothold & $\begin{array}{l}-0.0213 \\
{[0.94]}\end{array}$ & $\begin{array}{l}-0.022 \\
{[0.98]}\end{array}$ & $\begin{array}{l}-0.0399 \\
{[1.07]}\end{array}$ & $\begin{array}{l}-0.0417 \\
{[1.13]}\end{array}$ & $\begin{array}{l}0.025 \\
{[0.40]}\end{array}$ & $\begin{array}{l}0.0201 \\
{[0.33]}\end{array}$ & $\begin{array}{l}-0.0216 \\
{[0.91]}\end{array}$ & $\begin{array}{l}0.0273 \\
{[0.44]}\end{array}$ & $\begin{array}{l}0.031 \\
{[0.52]}\end{array}$ & $\begin{array}{l}0.0296 \\
{[0.52]}\end{array}$ & $\begin{array}{l}-0.0616 \\
{[5.60]^{* * *}}\end{array}$ & $\begin{array}{l}-0.0585 \\
{[4.74]^{\star * *}}\end{array}$ & $\begin{array}{l}-0.0735 \\
{[1.95]^{*}}\end{array}$ & $\begin{array}{l}-0.0841 \\
{[2.28]^{\star *}}\end{array}$ \\
\hline Prior local invest & $\begin{array}{l}-0.0146 \\
{[0.23]}\end{array}$ & $\begin{array}{l}-0.0165 \\
{[0.26]}\end{array}$ & $\begin{array}{l}0.0121 \\
{[0.19]}\end{array}$ & $\begin{array}{l}0.0119 \\
{[0.19]}\end{array}$ & $\begin{array}{l}0.0198 \\
{[0.21]}\end{array}$ & $\begin{array}{l}0.024 \\
{[0.26]}\end{array}$ & $\begin{array}{l}-0.0151 \\
{[0.24]}\end{array}$ & $\begin{array}{l}0.0141 \\
{[0.16]}\end{array}$ & $\begin{array}{l}-0.0061 \\
{[0.07]}\end{array}$ & $\begin{array}{l}0.0039 \\
{[0.04]}\end{array}$ & $\begin{array}{l}-0.0246 \\
{[2.09]^{* *}}\end{array}$ & $\begin{array}{l}-0.0224 \\
{[1.81]^{*}}\end{array}$ & $\begin{array}{l}-0.0937 \\
{[1.58]}\end{array}$ & $\begin{array}{l}-0.0936 \\
{[1.54]}\end{array}$ \\
\hline acq.ctry/indstr/year dum. & $\mathrm{Y} / \mathrm{Y} / \mathrm{Y}$ & $\mathrm{Y} / \mathrm{Y} / \mathrm{Y}$ & $\mathrm{Y} / \mathrm{Y} / \mathrm{Y}$ & $\mathrm{Y} / \mathrm{Y} / \mathrm{Y}$ & $\mathrm{Y} / \mathrm{Y} / \mathrm{Y}$ & Y/Y/Y & $\mathrm{Y} / \mathrm{Y} / \mathrm{Y}$ & $\mathrm{Y} / \mathrm{Y} / \mathrm{Y}$ & $\mathrm{N} / \mathrm{Y} / \mathrm{Y}$ & $\mathrm{N} / \mathrm{Y} / \mathrm{Y}$ & $\mathrm{N} / \mathrm{Y} / \mathrm{Y}$ & $\mathrm{N} / \mathrm{Y} / \mathrm{Y}$ & $\mathrm{N} / \mathrm{Y} / \mathrm{Y}$ & $\mathrm{N} / \mathrm{Y} / \mathrm{Y}$ \\
\hline Observations & 961 & 961 & 414 & 414 & 961 & 961 & 921 & 921 & 921 & 939 & 4018 & 4018 & 4018 & 4018 \\
\hline R-squared & 0.17 & 0.17 & 0.26 & 0.25 & 0.31 & 0.31 & 0.18 & 0.31 & 0.24 & 0.23 & 0.1 & 0.11 & 0.17 & 0.16 \\
\hline
\end{tabular}

${ }^{*}$ significant at $10 \% ;{ }^{* *}$ significant at $5 \% ;{ }^{* *}$ significant at $1 \%$. Robust t statistics in brackets. Corrected for possible correlation within target countries according to Froot (1989). 
Table 5: Target premium (dependent), corruption, and related aspects of governance

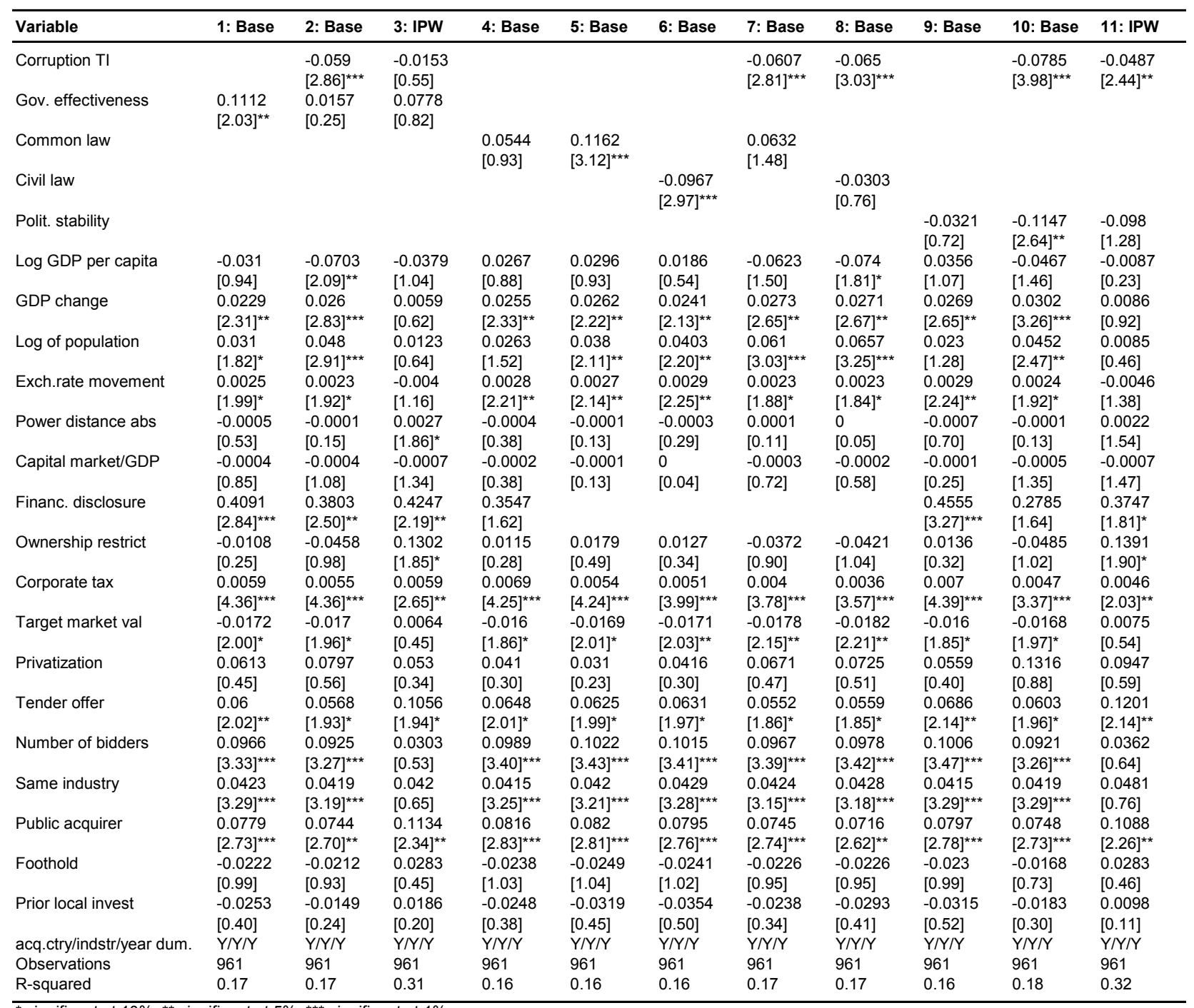

significant at $10 \%$

Robust $t$ statistics in brackets. Corrected for possible correlation within target countries according to Froot (1989). 


\section{Bibliography}

Anand, J. and Delios, A. (2002) 'Absolute and Relative Resourcesas Determinants of International Acquisitions', Strategic Management Journal, 23: 119-134.

Anand, J. and Kogut, B. (1997) 'Technological Capabilities of Countries, Firm Rivalry and Foreign Direct Investment', Journal of International Business Studies, 28(3): 445-465.

Andrade, G., Mitchell, M. and Stafford, E. (2001) 'New Evidence and Perspectives on Mergers', Journal of Economic Perspectives, 15: 103-120.

Bardhan, P. (1997) 'Corruption and Development: A Review of Issues', Journal of Economic Literature, 35: 1320-1346.

Bates, T. W. and Lemmon, M. L. (2003) 'Breaking Up is Hard to Do? An Analysis of Termination Fee Provisions and Merger Outcomes', Journal of Financial Economics, 69: 469-504.

Belsley, D.A.; Kuh, E.; and Welsch, R.E. (1980) Regression Diagnostics, John Wiley \& Sons, Inc.: New York.

Betton, S. and Eckbo, B. E. (2000) 'Toeholds, Bid Jumps, and Expected Payoffs in Takeovers', The Review of Financial Studies, 13(4): 841-882,

Brainard, L. (1997) 'An Empirical Assessment of the Proximity-Concentration Tradeoff Between Multinational Sales and Trade', American Economic Review, 87: 520-544.

Brunetti, A. and Weder, B. (1998) 'Investment and Institutional Uncertainty: A Comparative Study of Different Uncertainty Measures', Weltwirtschaftliches Archiv, 134: 513-533.

Chang, S.J. and Rosenzweig, P. (2001) 'The Choice of Entry Mode in Sequential Foreign Direct Investment', Strategic Management Journal, 22: 747-776.

Chatterjee, S. Lubatkin, M.H., Schweiger, D. M. and Weber, Y. (1992) 'Cultural Differences and Shareholder Value in Related Mergers Linking Equity and Human Capital', Strategic Management Journal, 13: 319-334.

Datta, D. and Puia, G. (1995) 'Cross-border Acquisitions: An Examination of the Influence of Relatedness and Cultural Fit on Shareholder Value Creation in U.S. Acquiring Firms, Management International Review, 35: 337-359.

DePamphilis, D.M. (2005) Mergers, Acquisitions, and Other Restructuring Activities, Elsevier Academic Press: Burlington, MA.Drabek and Payne, (2002) 'The Impact of Transparency on Foreign Direct Investment', Journal of Economic Integration, 17(4), 777-810.

Dewenter, K. L. (1995) 'Does the Market React Differently to Domestic and Foreign Takeover Announcements? Evidence from U.S. Chemical and Retail Industries', Journal of Financial Economics, 37: 421-441. 
Djankov, S., La Porta, R., Lopez-de-Silanes, F. and Shleifer, A. (2002) 'The Regulation of Entry', Quarterly Journal of Economics, CXVII, 1-37.

Froot, K. A. (1989) 'Consistent Covariance Matrix Estimation with Cross-sectional Dependence and Heteroskedasticity in Financial Data', Journal of Financial and Quantitative Analysis, 24: 333355.

Froot, K. A. (1993) Foreign Direct Investment, University of Chicago Press: Chicago.

Gatignon, H. and Anderson, E. (1988) 'The Multinational Corporation's Degree of Control over Foreign Subsidiaries: Am Empirical Test of a Transaction Cost Explanation', Journal of Law, Economics, and Organization, 4: 304-336.

Glaeser, E.L. and Shleifer, A (2002) 'Legal Origins', Quarterly Economic Journal, 117(4): 1193 1229.

Gleditsch, K. S. and Ward, M. D. (2001) 'Measuring Space: A Minimum Distance Database', Journal of Peace Research, 38: 749-68.

Gugler, K., Mueller, D. C., Yurtoglu, B. B. and Zulehner, C. (2003) 'The Effects of Mergers: An International Comparison', International Journal of Industrial Organization, 21 (5): 625-653. Habib, M. and Zurawicki, L. (2001) 'Country-level Investments and the Effect of Corruption Some Empirical Evidence', International Business Review, 10: 687-700.

Habib, M. and Zurawicki, L. (2002) 'Corruption and Foreign Direct Investment', Journal of International Business Studies, 33 (2): 291-307.

Hair, J., Anderson, R., Tatham, R. and Black, W. (1992) Multivariate Data Analysis, Macmillan: New York, NY.

Harris, R. S. and Ravenscraft, D. (1991) 'The Role of Acquisitions in Foreign Direct Investment: Evidence form the U.S. Stock Market', Journal of Finance, 46(3): 825-844.

Harzing, A.-W. (2003) 'The Role of Culture in Entry Mode Studies: From Negligence to Myopia?', Advances in International Management, 15: 75-127.

Henisz, W. J. (2000), The Institutional Environment for Multinational Investment', Journal of Law, Economics and Organization, 16 (2): 334-364.

Hofstede, G. (1980) Culture's Consequences: International Differences in Work-related Values, Sage: Newbury Park, CA.

Hines, J. R. Jr. (1995) 'Forbidden Payment: Foreign Bribery and American Business After 1977', National Bureau of Economic Research Working Paper 5266, Cambridge MA.

Huber, P. (1967) 'The Behavior of Maximum Likelihood Estimates Under Non-Standard Conditions', Proceedings of the Fifth Berkeley Symposium on Mathematical Statistics and Probability, vol. 1., University of California Press: Berkeley, CA, pp. 221-233. 
Huntington, S. (1968) Political Order in Changing Societies, Yale University Press: New Haven.

Husa, J. (2001) 'Legal Families and Research in Comparative Law', Global Jurist Advances, 1(3): Article 4.

Husted, B. W. (1994) ' Honor among Thieves: A Transaction-Cost Interpretation of Corruption in Third World Countries', Business Ethics Quarterly, 4 (1): 17-27.

Husted, Bryan W., 1999. Wealth, Culture, and Corruption. Journal of International Business Studies, 30 (2): 339-359.

Jarell, G., Brickley, J. and Netter, J. (1988) 'The Market for Corporate Control - The Empirical Evidence Since 1980', Journal of Economic Perspectives, 2: 49-68.

Jensen, M. and Ruback, R. (1983) 'The Market for Corporate Control - The Scientific Evidence', Journal of Financial Economics, 11: 5-50.

Kaufmann, D. and Wei S.-J. (1999) 'Does 'Grease Money’ Speed Up the Wheels of Commerce?', National Bureau of Economic Research Working Paper No. W7093.

Kaufmann, D., Kraay, A. and Zoido-Lobaton, P. (1999) 'Governance Matters', World Bank Policy Research Working Paper No. 2196, Washington, D.C.

Kaufmann, D., Kraay, A. and Zoido-Lobaton, P. (2002) 'Governance Matters II - Updated Indicators for 2000/01', World Bank Policy Research Working Paper No. 2772, Washington, D.C. Kaufmann, D., and Kraay, A. (2002) 'Growth without Governance', Economia, 3(1): 169-229.

Kaufmann, D. (2004) 'Corruption, Governance and Security: Challenges for the Rich Countries and the World', in The World Economic Forum, Global Competitivenss Report 2004 - 2005, Chapter 2.1., pp. 83-102.

Kaufmann, D., Kraay, A. and Mastruzzi, M. (2004) 'Governance Matters III: Governance Indicators for 1996, 1998, 2000 and 2002', World Bank Economic Review, 18: 253-287.

Kaufmann, D. (2005) 'Myths and Realities of Governance and Corruption', in The World Economic Forum, Global Competitivenss Report 2005 - 2006, Chapter 2.1., pp. 81-98.

Kaufmann, D., Kraay, A. and Mastruzzi, M. (2005) 'Governance Matters IV: Governance Indicators for 1996-2004', World Bank Policy Research Working Paper No. 3630, Washington, D.C.

Keefer, P. and Knack, S. (1995) 'Institutions and Economic Performance: Cross-Country Tests Using Alternative Institutional Measures', Economics and Politics, 7 (3): 207-227.

Kobrin, S. (1976) 'The Environmental Determinants of Foreign Direct Manufacturing Investment: An Expost Empirical Analysis', Journal of International Business Studies, 7(1): 29-42.

Kogut, B. and Singh, H. (1988) 'The Effect of National Culture on Choice of Entry Mode', Journal of International Business Studies, 49(Fall): 411-430 
Lambsdorff, J. Graf. (1999) ‘ The Transparency International Corruption Perceptions Index 1999 Framework Document', Working Paper, Transparency International, Berlin.

Lambsdorff, J. Graf. (2002) 'Making Corrupt Deals: Contracting in the Shadow of Law', Journal of Economic Behavior \& Organization, 48: 221-241.

La Porta, R., Lopez-de-Silanes, F., Shleifer, A. and Vishny, R. W. (1997) 'Legal Determinants of External Finance,' Journal of Finance, 52: 1131-1150.

La Porta, R., Lopez-de-Silanes, F., Shleifer, A. and Vishny, R. W. (1998) 'Law and Finance' Journal of Political Economy, CVI: 1113-1155.

La Porta, R., Lopez-de-Silanes, F., Shleifer, A. and Vishny, R. W. (1999) 'The Quality of

Government' Journal of Law, Economics, and Organization, 15: 222-279.

La Porta, R., Lopez-de-Silanes, F., Shleifer, A. and Vishny, R. W. (2000) 'Investor Protection and Corporate Governance', Journal of Financial Economics, 58: 3-27.

La Porta, R., Lopez-de-Silanes, F., Shleifer, A. and Vishny, R. W. (2002) 'Investor Protection and Corporate Valuation', Journal of Finance, 57(3): 1147-1170.

La Porta, R., Lopez-de-Silanes, F. and Shleifer, A. (2006) 'What works in securities laws?', Journal of Finance, 61(1): 1-32.

Leff, N. (1964) 'Economic Development Through Bureaucratic Corruption', American Behavioral Scientist, 8: 8-14.

Li, J. and Guisinger, S. (1991) 'Comparative Business Failures of Foreign Investment:

Determinants of the Dispersion of Profits After Large Outcomes', Journal of International Business Studies, 22: 209-224.

Malta Conference (1994) 'Report of the Netherlands Ministry of Justice', Proceedings of the 19th Conference of the European Ministers of Justice, La Valetta 14-15th of June, 1994. Council of Europe Publishing: Strasbourg.

Markides, C. C. and Ittner, C. D. (1994) 'Shareholder Benefits from Corporate International Diversification: Evidence from U.S. International Acquisitions', Journal of International Business Studies, 25: 343-367.

Mattei, U. (1997) 'Three Patterns of Law: Taxonomy and Change in the World's Legal Systems', American Journal of Comparative Law, 45(1): 5-44

Mattei, U. (1999) Comparative Law and Economics, University of Michigan Press: Ann Arbor.

Mauro, P. (1995) ‘Corruption and Growth', Quarterly Journal of Economics, 110 (3): 681-712.

MacRae, J. (1982) 'Underdevelopment and the Economics of Corruption: A Game Theory Approach', World Development, 10 (8): 677-687. 
Mo, P. H. (2001) 'Corruption and Economic Growth', Journal of Comparative Economics, 29: 6679.

Mutthoo A. (1999) Bargaining Theory with Applications, Cambridge University Press: Cambridge. Officer, M. S. (2003) 'Termination Fees in Mergers and Acquisitions', Journal of Financial Economics, 69: 431-467.

Pacter, P. (2005) 'What Exactly is Convergence?', International Journal of Accounting, Auditing and Performance Evaluation, 2 (1/2): 67-83.

Pagano, M., and Volpin, P. F. (2005) 'Shareholder Protection, Stock Market Development, and Politics', ECGI Working Paper 105/2005.

Pellegrini, L. and Gerlagh, R. (2004) 'Corruption's Effect on Growth and its Transmission Channels', Kyklos, 57 (3): 429-456.

Reuer, J. J., Shenkar, O. and Ragazzino, R. (2004) 'Mitigating Risk in International Mergers and Acqusitions: The Role of Contingent Payouts', Journal of International Business Studies, 35: 1932.

Robertson, C. J. and Waterson A. (2004) 'Corruption and Change: The Impact of Foreign Direct Investment', Strategic Management Journal, 25: 385-396.

Rodriguez, P., Uhlenbruck, K. and Eden, L. (2005) 'Corrupt Governments Matter: How Corruption Affects the Entry Strategies of Multinationals', Academy of Management Review, forthcoming.

Rose-Ackerman, S. (1999) Corruption and Government: Causes; Consequences and Reform, Cambridge University Press: Cambridge.

Rossi, S. and Volpin, P. (2004) 'Cross-Country Determinants of Mergers and Acquisitions', Journal of Financial Economics, 74: 277-304

Schwert, G. W. (2000) 'Hostility in Takeovers: In the Eyes of the Beholder?', Journal of Finance, 55: 2599-2640.

Shimizu K., Hitt, M. A., Vaidyanath, D., and Pisano, V. (2004) 'Theoretical Foundations of Crossborder Mergers and Acquisitions: A Review of Current Research and Recommendations for the Future', Journal of International Management, 10: 307-353.

Shleifer, A. (2000) 'Comment', Brookings Papers on Economic Activity, 2(3): 347-350.

Shleifer, A. and Vichny, R. (1993) 'Corruption', Quaterly Journal of Economics, 108: 599-617. Smarzynska, B., and Wei, S.-J. (2000) 'Corruption and the Composition of Foreign Direct Investment: Firm-level Evidence', National Bureau of Economic Research Working Paper 7969, Cambridge MA. 
Stansbury, N. (2005) 'Exposing the foundations of corruption in construction', Global Corruption Report, 36-50.Studenmund, A. H. (1992) Using Econometrics: A Practical Guide, Harper Collins: New York, NY.

Stulz, R.M. (2005) 'The Limits of Financial Globalization', Journal of Finance, 60 (4): 1595-1638. The World Bank (1997) World Development Report, Washington, DC.

Uhlenbruck, K., Rodriguez, P., Doh, J., and Eden, L. (2006) 'The impact of corruption on entry strategy: evidence from telecommunications projects in emerging economies', Organization Science, forthcoming.

UNCTAD (2000) World Investment Report, Geneva, Switzerland.

Wei, S.-J. (2000) 'Local Corruption and Global Capital Flows', Brookings Papers on Economic Activity, 2: 303-354.

Wei, S.-J. (2000a) 'How Taxing is Corruption on International Investors?' Review of Economics and Statistics, 82 (1): 1-11.

White, H. (1980) 'A Heteroskedasticity-Consistent Covariance Matrix Estimator and a Direct Test for Heteroskedasticity', Econometrica, 48: 817-838.

Wooldridge, J. M. (2002) Econometric Analysis of Cross Section and Panel Data, MIT Press:

Cambridge, MA.

Wooldridge, J. M. (2003) Introductory Econometrics. 2nd edition, Thomson South-Western: Mason, $\mathrm{OH}$.

Zhao, H., Kim, S. H., and Du J. (2003) 'The Impact of Corruption and Transparency on Foreign Direct Investment: An Empirical Analysis', Management International Review, 43: 41-62.

Zweigert, K. and Kötz, H. (1998) An Introduction to Comparative Law (3d rev. ed.), Oxford University Press: New York, NY. 